\title{
BROMELIACEAE NA APA SANTUÁRIO ECOLÓGICO DA PEDRA BRANCA, CALDAS, MINAS GERAIS
}

\author{
AMÁLIA EUGÊNIA MATAVELLI ROSA \& REINALDO MONTEIRO
}

\begin{abstract}
Departamento de Botânica, Instituto de Biociências, Universidade Estadual Paulista, campus de Rio Claro, Avenida 24A, 1515, Bela Vista, 13506-900 - Rio Claro, SP, Brasil. amaliabio@yahoo.com.br
\end{abstract}

\begin{abstract}
Bromeliaceae in the APA Santuário Ecológico da Pedra Branca, Caldas, Minas Gerais). The Environmental Protection Area Ecological Sanctuary of Pedra Branca is located in the municipality of Caldas, southern Minas Gerais state. In their $119 \mathrm{~km}^{2}$, the altitude is always above $1000 \mathrm{~m}$, reaching $1760 \mathrm{~m}$ in the Pedra Branca. The region of Caldas raises interest since the mid-nineteenth century, when the naturalist Anders $F$. Regnell conducted extensive collections of local flora, listing several species of Bromeliaceae. Of 19 species of Bromeliaceae identified, Tillandsia (9 species), Aechmea (3) and Vriesea (3) were the best represented genera, while Billbergia, Bromelia, Dyckia and Wittrockia showed only one species. It is described for the first time the occurrence of $T$. pohliana, $T$. recurvata, $T$. streptocarpa and $T$. tricholepis in the study area, despite intensive Regnell expeditions. Two species are rediscovered at the type locality and six have exclusive habitat. The greater diversity of Bromeliaceae occurs along the Serra da Pedra Branca, is due to the integrity of the flora or a combination of altitude, climate and topography that favour the emergence of a mosaic of vegetation types. Key words: Bromeliaceae, Caldas, A. F. Regnell, Serra da Pedra Branca.
\end{abstract}

Key words: Montane vegetation, Atlantic forest, Titllandsia, Aechmea, Vriesea.

Resumo - (Bromeliaceae na APA Santuário Ecológico da Pedra Branca, Caldas, Minas Gerais). A Área de Proteção Ambiental Santuário Ecológico da Pedra Branca localiza-se no município de Caldas, sul de Minas Gerais. Nos seus $119 \mathrm{~km}^{2}$, a altitude é sempre superior a $1000 \mathrm{~m}$, chegando a $1760 \mathrm{~m}$ na Pedra Branca. A região de Caldas desperta interesse desde a segunda metade do século XIX, quando o naturalista Anders F. Regnell realizou amplas coletas da flora local, listando várias espécies de Bromeliaceae. Foram catalogadas 19 espécies de Bromeliaceae: Tillandsia (9 espécies), Aechmea (3) e Vriesea (3) foram os gêneros melhor representados, enquanto Billbergia, Bromelia, Dyckia e Wittrockia apresentaram somente uma espécie. É descrita pela primeira vez a ocorrência de $T$. pohliana, $T$. recurvata, $T$. streptocarpa e $T$. tricholepis na área de estudo, apesar das intensas expedições de Regnell. Duas espécies foram reencontradas na localidade típica e seis apresentam exclusividade de habitat. A maior diversidade de Bromeliaceae ocorre ao longo da Serra da Pedra Branca, seja pela integridade da flora ou pela combinação entre altitude, clima e relevo que propiciam o surgimento de um mosaico de fisionomias. Palavras chave: Bromeliaceae, Caldas, A. F. Regnell, Serra da Pedra Branca.

Palavras-chave: Campo-de-altitude, Mata Atlântica, Tillandsia, Aechmea, Vriesea.

\section{Introdução}

Bromeliaceae é atualmente composta por 58 gêneros e 3172 espécies (Luther 2008), sendo que 42 gêneros e 1207 espécies ocorrem no Brasil (Forzza et al. 2010). A costa leste brasileira é considerada um centro de diversidade da família, com destaque para os estados da região Sudeste e o sul da Bahia que abrigam $50 \%$ das espécies inventariadas para o domínio Mata Atlântica, com cerca de $10 \%$ dos gêneros endêmicos desta formação (Martinelli et al. 2008). Dentro das divisões geomorfológicas do Sudeste, eleva-se o Planalto Sul de Minas na região de Poços de Caldas, formado por um anel de cristas que delimita uma zona rebaixada no interior (Tinós 2011). Nas bordas da caldeira de Poços de Caldas, na sua porção sudeste, encontra-se a Área de Proteção Ambiental Santuário Ecológico da Pedra Branca, no município de Caldas. Esse município, localidade típica de várias espécies botânicas, tornou-se conhecido graças aos quase 40 anos de dedicação do naturalista sueco Anders F. Regnell. Com exceção dos hóspedes que recebia, naturalistas como ele, Regnell ficava isolado da comunidade científica, sem interação com os conhecimentos botânicos e taxonômicos produzidos na Europa. Como seu objetivo era apresentar a flora brasileira à Europa, colecionou e conservou suas coleções de planta por longos anos. Regnell estabeleceu contato com vários botânicos famosos, dentre eles o brasileiro João Barbosa Rodrigues. Parte de suas coleções foram enviadas a Carl Friedrich Philip von Martius, que as incluiu na "Flora Brasiliensis" (Quezada, com. pessoal). A maior parte das coleções de Regnell encontra-se depositada no herbário do museu de história natural de Estocolmo (Dahlgren 1962). Embora citado por este autor que o herbário do Museu Nacional do Rio de Janeiro tivesse recebido duplicatas da coleção de Regnell, as consultas a este herbário mostraram que muito pouco da flora de Bromeliaceae de Caldas está lá depositada. Apesar de suas expedições na região, as etiquetas de Regnell não precisam exatamente os 
locais de suas coletas. Como Caldas, nos anos em que Regnell lá esteve abrangia uma área bem maior do que a atual (Pimenta 1998), espécies lá coletadas podem, na verdade, ter sido coletadas a muitos quilômetros de distância dos limites municipais atuais. Felizmente, quando se trata das coletas na Pedra Branca, principal atributo geomorfológico da região, as etiquetas são informativas. Isso é de grande valor científico, já que muitas espécies-tipo foram coletadas nesta localidade. Desde a morte de Regnell, em 1884, até o final da década de 2000 , não foram realizados estudos botânicos em Caldas. Contudo, a criação da APA Santuário Ecológico da Pedra Branca ampliou o interesse científico pela região, impulsionando alguns estudos. Além do presente trabalho, vários outros têm dado atenção especial às Bromeliaceae de Minas Gerais, principalmente em áreas de Mata Atlântica e Campos Rupestres. Algumas espécies citadas aqui foram tratadas também por Paula (1998), Versieux e Wendt (2006), Martinelli et al. (2008), Lima (2008), Coffani-Nunes et al. (2010), dentre outros. Entretanto, as observações de campo obtidas em relação à distribuição das espécies da ASEPB, uma área tão diversa quanto às fisionomias vegetais, serão relevantes para ampliar o conhecimento sobre as espécies listadas. Além disso, por se tratar de uma unidade de conservação recém criada (2006) e pela sua localização em uma região geomorfógica tão particular, o presente estudo pode direcionar futuras ações conservacionistas. Assim, este trabalho objetivou a realização de um estudo florístico sobre as Bromeliaceae, a retomada dos trabalhos de caráter taxonômico e florísticos iniciados por Regnell na região, a comparação entre as espécies coletadas por ele e as recentemente encontradas, e o estabecimento de um diagnóstico sobre o estado de conservação desta unidade de conservação.

\section{Material e Métodos}

A sudoeste do município de Caldas (Fig. 1) localiza-se a Área de Preservação Ambiental Santuário Ecológico da Pedra Branca (ASEPB) (Fig. 2), compreendendo uma área de $11.955,433$ ha $\mathrm{e}$ altitude entre 1000 e 1760m (Conforti et al. 2007). Seu relevo é irregular, formado por "mares de morros", com solos mais espessos e de diversas composições graníticas, e por regiões serranas, constituídas por rochas sieníticas, como a Serra da Pedra Branca (Winters 1981), cujo ponto culminante é a Pedra Branca. Na APA, destaca-se também a Serra da Pedra do Coração (prolongamento da Serra da Pedra Branca), uma Reserva Biológica Municipal (lei 327/1988). A região de Caldas apresenta temperaturas médias entre $15,4-18^{\circ} \mathrm{C}$, com índices pluviométricos entre 1648-1762 $\mathrm{mm}$ anuais (Scolforo et al. 2008). De acordo com a classificação de Köppen, o clima é do tipo Cwb, subtropical de altitude, com inverno seco e verão ameno (Winters 1981). As fisionomias vegetais encontradas na ASEPB formam um complexo mosaico, com predomínio de Floresta Estacional Semidecidual (Veloso et al. 1991). Incluemse neste mosaico Campos de Altitude e Floresta Estacional Semidecidual Montana (FESM) e Altomontana (FESA), segundo Veloso et al. (1991), além do Cerradão e dos aqui denominados Campos Rochosos. Embora a fisionomia de Cerradão não tenha sido citada para a região até então, as observações de campo permitiram reconhecer uma vegetação extrememente repetitiva, com ausência de sub-bosque, a qual Veloso et al. (1991) chamaram de Cerradão. Os denominados Campos Rochosos são áreas de terreno rochoso onde a vegetação florestal original, portanto consideravelmente diferente de Campos de Altitude e de Campos Rupestres, foi suprimida pela ação antrópica. $O$ estado de conservação das fisionomias na ASEPB está diretamente relacionado à facilidade de acesso. Os terrenos rochosos localizados ao longo da Serra da Pedra Branca apresentam potencial minerário e, em alguns pontos, encontram-se bastante descaracterizados. Dada a grande quantidade de empresas mineradoras na região, a lei de criação da APA (1973/2006) proibiu a atividade de mineração em toda sua extensão, com exceção das já instaladas e com as devidas licenças de operação.

O material botânico foi coletado entre julho/2009 e dezembro/2010, quinzenal ou mensalmente, dependendo da disponibilidade de indivíduos férteis. Exsicatas de 200 espécimes, muitas delas com duplicata, encontram-se depositadas no herbário HRCB. Foram consultadas parte do acervo de Bromeliaceae dos herbários SP, R, RB e HRCB e integralmente o banco de dados on line dos herbários S, NY e US (acrônimos segundo Holmgren et al. 1990). Os materiais anteriormente coletados por Regnell, os coletados no Planalto Sul de Minas e os que configuram novas ocorrências não citadas na literatura consultada foram listados em "material adicional". Apesar de grande parte da coleção de Regnell estar depositada no herbário $S$, o empréstimo de suas exsicatas foi negado, alegando-se ausência de identificação de muitas das exsicatas daquele acervo, além das dificuldades institucionais para separação, embalagem e envio do material solicitado. Além disso, a consulta ao banco de dados on line das instituições anteriormente citadas revelaram a existência de poucos registros de coleta atribuídos a Regnell para o município de estudo, sendo que alguns deles não apresentavam fotos digitais. Diante disso, optou-se pela utilização de material elaborado por outros autores, principalmente por Smith e Downs (1974, 1977, 1979), pois, tratando-se da coleção histórica de Regnell, os dados publicados por eles continuam sendo os mais abrangentes e atuais. Assim, a comparação entre o material atualmente coletado e aquele coletado por Regnell baseou-se principalmente em Smith e Downs (1974, 1977, 1979), Versieux e Wendt (2006) e em consulta aos herbários citados. Utilizou-se Raddford et al. (1974) para 

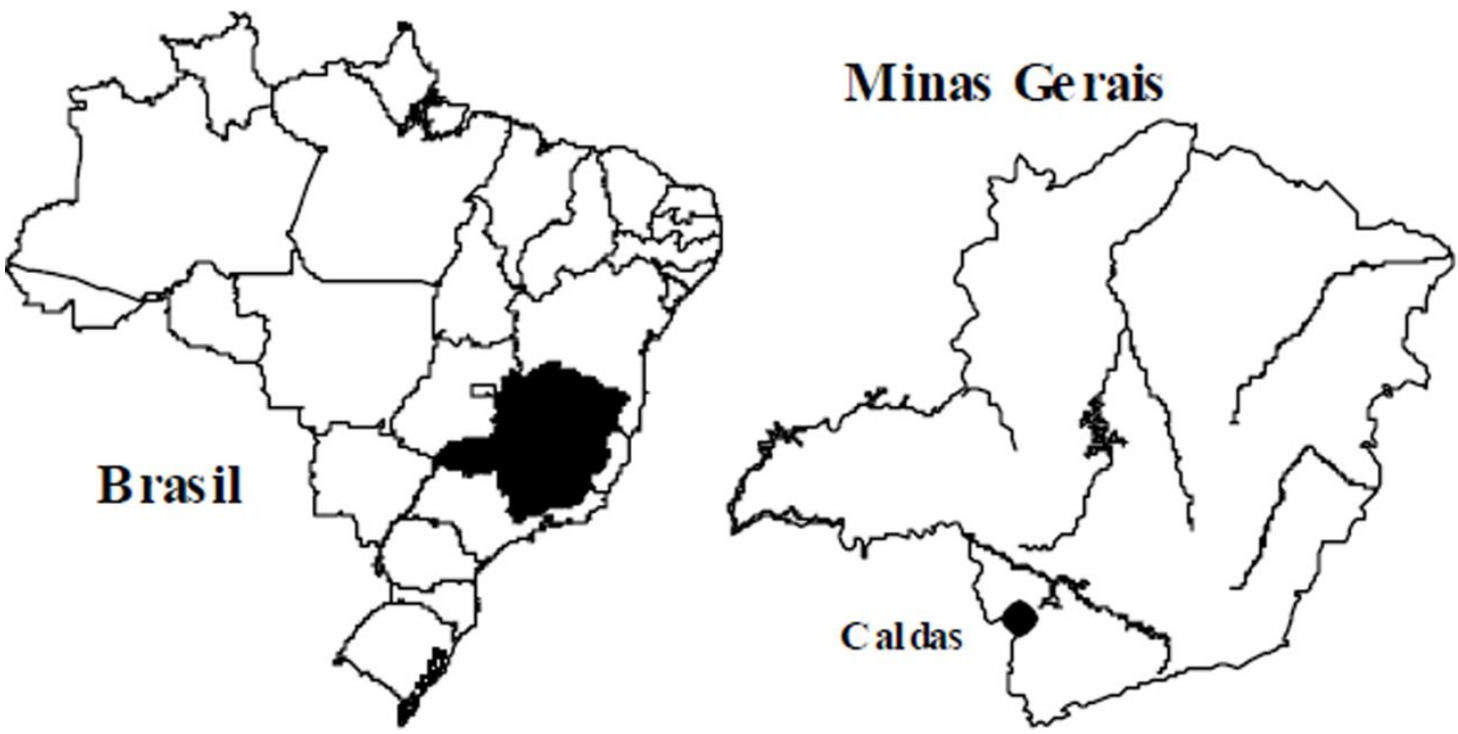

Fig. 1. Localização do município de Caldas, Minas Gerais. Fonte: Conforti et al. (2007).

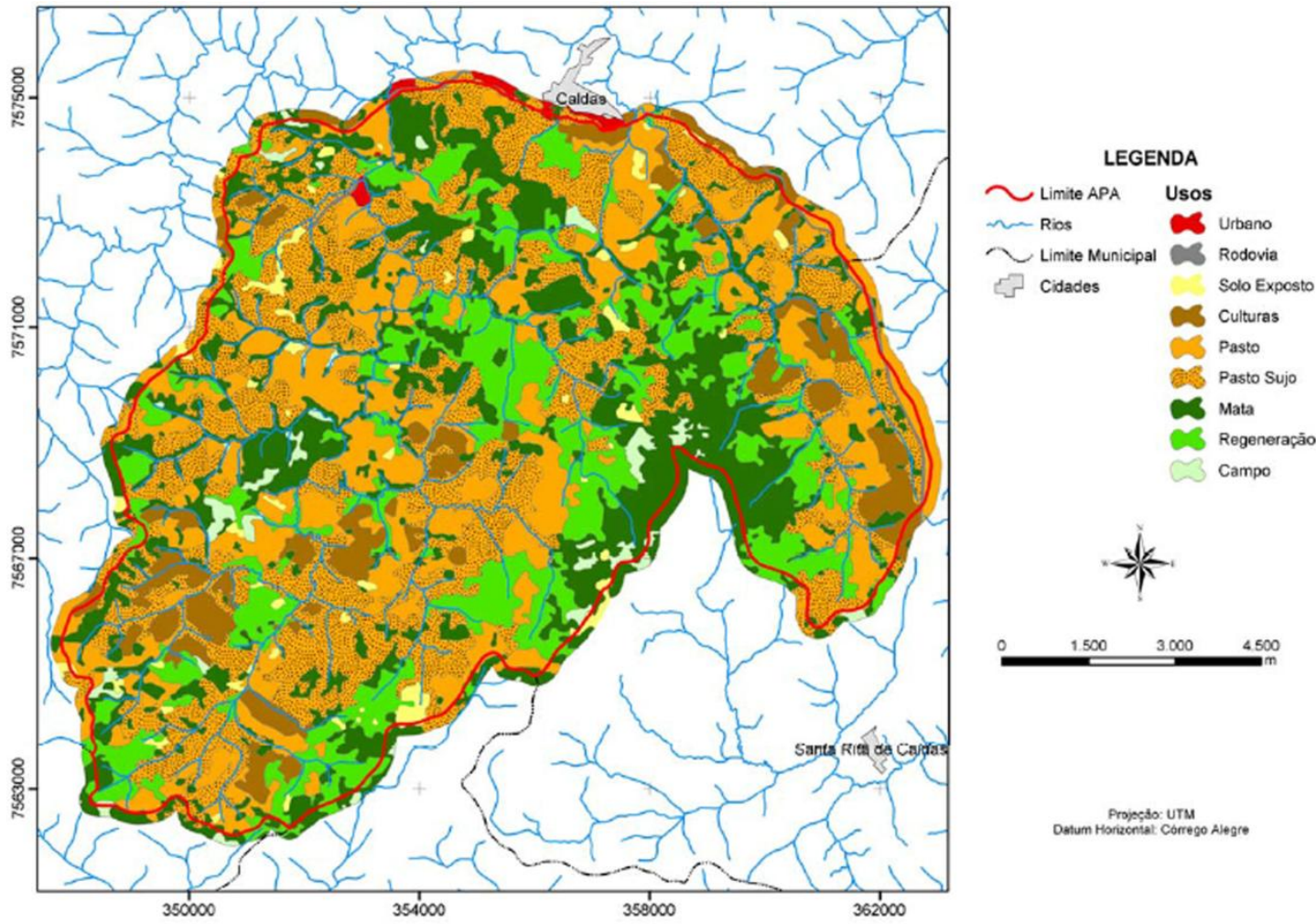

Fig. 2. Usos da terra na Área de Preservação Ambiental "Santuário Ecológico da Pedra Branca”. Fonte: Conforti et al. (2007). 
padronizar as descrições quanto à morfologia. A altura foi tomada com base nos indivíduos férteis, incluindose a inflorescência. Para cada espécie anotou-se a distribuição geográfica, descrição, material examinado e comentários a respeito dos aspectos taxonômicos relevantes, época de floração, frutificação.

\section{Resultados e discussão}

Foram identificadas 19 espécies de Bromeliaceae, pertencentes a sete gêneros. Os gêneros melhor representados foram Tillandsia (9 spp.), Aechmea (3 spp.) e Vriesea (3 spp.), enquanto Billbergia, Bromelia, Dyckia e Wittrockia apresentaram somente uma espécie. Do total, 15 espécies foram coletadas por Regnell e quatro são novas ocorrências para Caldas ( $T$. pohliana, $T$. recurvata, $T$. streptocarpa e T. tricholepis). Foram encontradas espécies com exclusividade de habitat: Billbergia distachia var. distachia, $V$. friburgensis var. tucumanensis e $V$. regnellii (FESM); Dyckia minarum e V. sceptrum (Campos de Altitude); Wittrockia cyathiformis (FESA). Uma das espécies coletada por Regnell, Pitcairnia lanuginosa Ruiz \& Pavon, não foi encontrada. A antropização pode ter influenciado a perda de seu habitat ou ainda, a mesma pode se encontrar em escarpas que excedem os limites da ASEPB. Apesar das intervenções humanas terem comprometido intensamente o interior da APA, acredita-se que a flora de Bromeliaceae esteja ainda bem representada na região, se comparada às coletas atribuídas a Regnell para Caldas. Mesmo que a dificuldade de acesso contribua positivamente para a maior diversidade de Bromeliaceae ao longo da Serra da Pedra Branca, a integridade da flora e a combinação de fatores edáficos que propiciam ambientes diferentes em um curto espaço são essenciais para explicá-la.

Chave para identificação das espécies de Bromeliaceae ocorrentes na ASEPB

1. Folhas com margens espinescentes, ovário súpero ou ínfero, fruto cápula ou baga, sementes achatadas e aladas ou sementes sem apêndices.

2. Ovário súpero, fruto cápsula, sementes achatadas e aladas (Subfamília Pitcairnioideae),

pétalas alaranjadas, obtruladas............................................................................................. . Dyckia minarum

2'. Ovário ínfero, fruto baga, sementes sem apêndices (Subfamília Bromelioideae), pétalas amarelas, amarelo-esverdeadas, verdes ou roxas, oblongas, espatuladas ou liguladas.

3. Folhas centrais vermelhas, com ápice verde na fase reprodutiva

5. Bromelia regnellii

3'. Folhas concolores.

4. Inflorescência simples.

5. Inflorescência pêndula, raque geniculada, flores zigomorfas

5'. Inflorescência ereta ou subereta, raque não geniculada.

6. Inflorescência congesta, estrobiliforme, raque encoberta pelas

flore

6'. Inflorescência laxa ou densa, cilíndrica, raque exposta

.. 3. Aechmea nudicaulis var. cuspidata

4'. Inflorescência composta.

7. Inflorescência densa a laxa, brácteas florais parcialmente conatas aos entrenós, sépalas assimétricas .....

7'. Inflorescência subcorimbosa, brácteas florais livres, sépalas subsimétricas ............6. Wittrockia cyathiformis

4. Aechmea distichantha

1'. Folhas com margens inteiras, ovário súpero, fruto cápsula, sementes com apêndices (Subfamília

Tillandsioideae).

8. Roseta não formando tanque, apêndices petalíneos ausentes.

9. Inflorescência composta.

10. Inflorescência laxa, flores dísticas, ramos complanados

10'. Inflorescência densa, flores polísticas, ramos não-complanados.

11. Lâmina argêntea, densamente lepidota, escamas ultrapassando a margem foliar, inflorescência globosa...

11'. Lâmina esverdeada, lepidota, escamas não ultrapassando a margem foliar, inflorescência piramidal.

12. Tillandsia streptocarpa

9'. Inflorescência simples.
12. Inflorescência uniflora, planta pendente nos ramos das árvores, raízes ausentes na

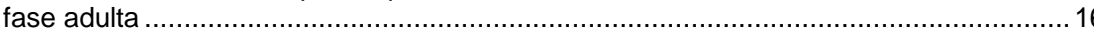

.. 8. Tillandsia gardneri

9. Tillandsia geminiflora

12'. Inflorescência com 2 ou mais flores, planta não pendente, raízes presentes na fase adulta.

13. Flores dísticas.

14. Pétalas espatuladas

12. Tillandsia streptocarpa

14'. Pétalas liguladas.

15. Pétalas amarelas, ápice agudo, anteras basifixas

5. Tillandsia tricholepis

15'. Pétalas lilás, ápice obtuso, anteras dorsifixas....

11. Tillandsia recurvata

13'. Flores polísticas.

16. Sépalas coriáceas, densamente lepidotas, pétalas alvas

10. Tillandsia pohliana

16 '. Sépalas membranáceas, glabras, pétalas roxas, róseas ou alvas. 
Bromeliaceae na APA da Pedra Branca, Caldas, Minas Gerais

17. Inflorescência globosa a subglobosa, densa, sépalas curto-conatas, pétalas roxas ou róseas, estames livres................................................................13. T. stricta var. stricta

17'. Inflorescência ovóide a cilíndrica, subdensa, sépalas livres, curto-conatas ou conatas até a metade, pétalas roxas, róseas ou alvas, filetes internos adnatos à base das pétalas 14. Tillandsia tenuifolia

8'. Roseta formando tanque, apêndices petalíneos presentes.

18. Inflorescência simples, racemosa, antese noturna.

18'. Inflorescência composta, em racemo heterotético duplo, antese diurna.

19. Sépalas estreito-elípticas, estames inclusos 18. Vriesea regnellii

19'. Sépalas elípticas, estames exsertos

19. Vriesea sceptrum 17. Vriesea friburgensis var. tucumanensis

\section{Bromelioideae}

1. Aechmea bromeliifolia var. albobracteata Philcox, Ashingtonia 1(8): 92. 1974.

Fig. 3. A.

Epífita ou terrestre, $73-108 \mathrm{~cm}$ alt. Roseta tubular. Folhas 53,5-112 cm compr., alternoespiraladas, congestas; bainha castanho-clara, 17$26 \times 7,5-13,5 \mathrm{~cm}$, oval a elíptica, margens inteiras a espinescentes para o ápice; lâmina verde, 34-90×3-6,3 $\mathrm{cm}$, lanceolada a estreito-triangular, ápice acuminado, mucronado, margens espinescentes, espinhos castanhos, 3-7 mm compr., antrorsos. Escapo esverdeado, 64-95 cm compr., alvo-lanuginoso; brácteas escapais alvas, 5,5-17x2,5-4,5 cm, ovadas a lanceoladas, ápice agudo a acuminado, mucronado, margens inteiras, alvo-lanuginosas, inbricadas, recobrindo o escapo, as proximais ultrapassando os entrenós. Inflorescência 7-12,5×2,5-4 cm de diâm., simples, estrobiliforme, congesta, raque alvolanuginosa, ereta, totalmente encoberta pelas flores; brácteas florais verdes, 0,6-1x1,1-1,7 cm, ovadas, coriáceas, mais curtas que as sépalas, envolvendo o ovário, truncadas, bicarenadas, margens inteiras. Flores 1,1-1,4 cm compr., sésseis, polísticas; sépalas verdes, $0,6-0,7 \times 0,3-0,4 \mathrm{~cm}$, assimétricas, conatas na base cerca 1-2 $\mathrm{mm}$; pétalas amarelo-esverdeadas, 0,9-1,1 $\times 0,1-0,15 \mathrm{~cm}$, oblongas, eretas, negras após antese; filetes internos adnatos à base das pétalas, estames inclusos, anteras dorsifixas. Frutos globosos. Sementes fusiformes.

Material examinado: Minas Gerais, Caldas, ASEPB, 13.I.2010, A. E. M. Rosa 195 (HRCB); 16.VII.2010, A. E. M. Rosa 279 (HRCB); beira de estrada, 3.VIII.2010, A. E. M. Rosa 291 (HRCB); 30.VIII.2010, A. E. M. Rosa 307 (HRCB); beira de estrada, 11.X.2010, A. E. M. Rosa 345 (HRCB).

Aechmea bromeliifolia var. albobracteata ocorre da Argentina e Paraguai ao centro, sul e sudeste do Brasil, em Mato Grosso, Mato Grosso do Sul, Minas Gerais, São Paulo e Paraná, crescendo entre 100 e 900m de altitude, em Floresta Semidecídua, Cerrados e Campos Rupestres (Faria et al. 2010). Na ASEPB, ocorre como epífita em forófitos isolados nos Campos Rochosos em regeneração, no interior e borda de FESM e Cerradão, entre 1300 e 1500m de altitude. É freqüente também em áreas antropizadas, pastos e beiras de estradas. Faria et al. (2010) relatam a ocorrência de $A$. bromeliifolia var. albobracteata em alguns município mineiros (Barroso, Lambari, Santo Antônio do Itambé, São Gonçalo do Rio Preto, Uberlândia e Viçosa). Consultando as duas exsicatas de $A$. bromeliifolia referidas para Caldas em Smith e Downs (1977), ambas do coletor Regnell, Faria et al. (2010) revelaram que trata-se de Aechmea bromeliifolia var. bromeliifolia. Durante a execução do presente trabalho, somente $A$. bromeliifolia var. albobracteata foi encontrada. Na ASEPB, a espécie floresce em julho e agosto e frutifica em agosto e outubro.

2. Aechmea distichantha Lem., Jard. Fleur. 3: $t$. 269. 1853.

Fig. 3. B-D.

Epífita, rupícola ou saxícola, $43-111 \mathrm{~cm}$ alt. Roseta aberta ou tubular. Folhas $33-83 \mathrm{~cm}$ compr., alterno-espiraladas, congestas; bainha vinácea na face adaxial, $10-22 \times 5-8,5 \mathrm{~cm}$, elíptica a oblonga, mais larga do que a lâmina; lâmina verde a avermelhada, 24-64x1,2-3,2 cm, linear-triangular a estreitotriangular, às vezes ligulada, ápice pungente, margens serrilhadas a espinescente, espinhos castanhoescuros, 1-5 mm compr, antrorsos. Escapo 30-80 cm compr., recoberto pelas brácteas, ereto, lanuginoso; brácteas escapais alvo-esverdeadas ou róseas, 11,529×2-5 cm, elípticas, ápice agudo, mucronado, imbricadas, margens inteiras. Inflorescência 7,3$18 \times 2,5-6,5 \mathrm{~cm}$ de diâm., composta, cilíndrica ou piramidal, densa a laxa, raque rósea a vermelha, alvolanuginosa, exposta, ereta; ramos com 3-8 flores disticamente dispostas; brácteas primárias róseas, mais curtas que os ramos, largo-ovadas, ápice mucronado, margens inteiras; brácteas florais róseas, 0,6-0,9 $\times 1,1-1,2 \mathrm{~cm}$, transversalmente ovadas, envolvendo completamente o ovário, decorrentes, parcialmente envolvendo os entrenós, mucronadas, margens inteiras, nervadas. Flores 1,9-2,4 cm compr., sésseis, dísticas; sépalas róseas, 0,8-1,2×0,3-0,5 cm, assimétricas, conatas na base cerca de 1-3 mm, ápice mucronado; pétalas roxas, 1,3-1,7x0,3-0,4 cm, espatuladas, eretas, ápice retuso; filetes internos adnatos à base das pétalas, estames inclusos, anteras dorsifixas. Frutos globosos. Sementes não vistas. 


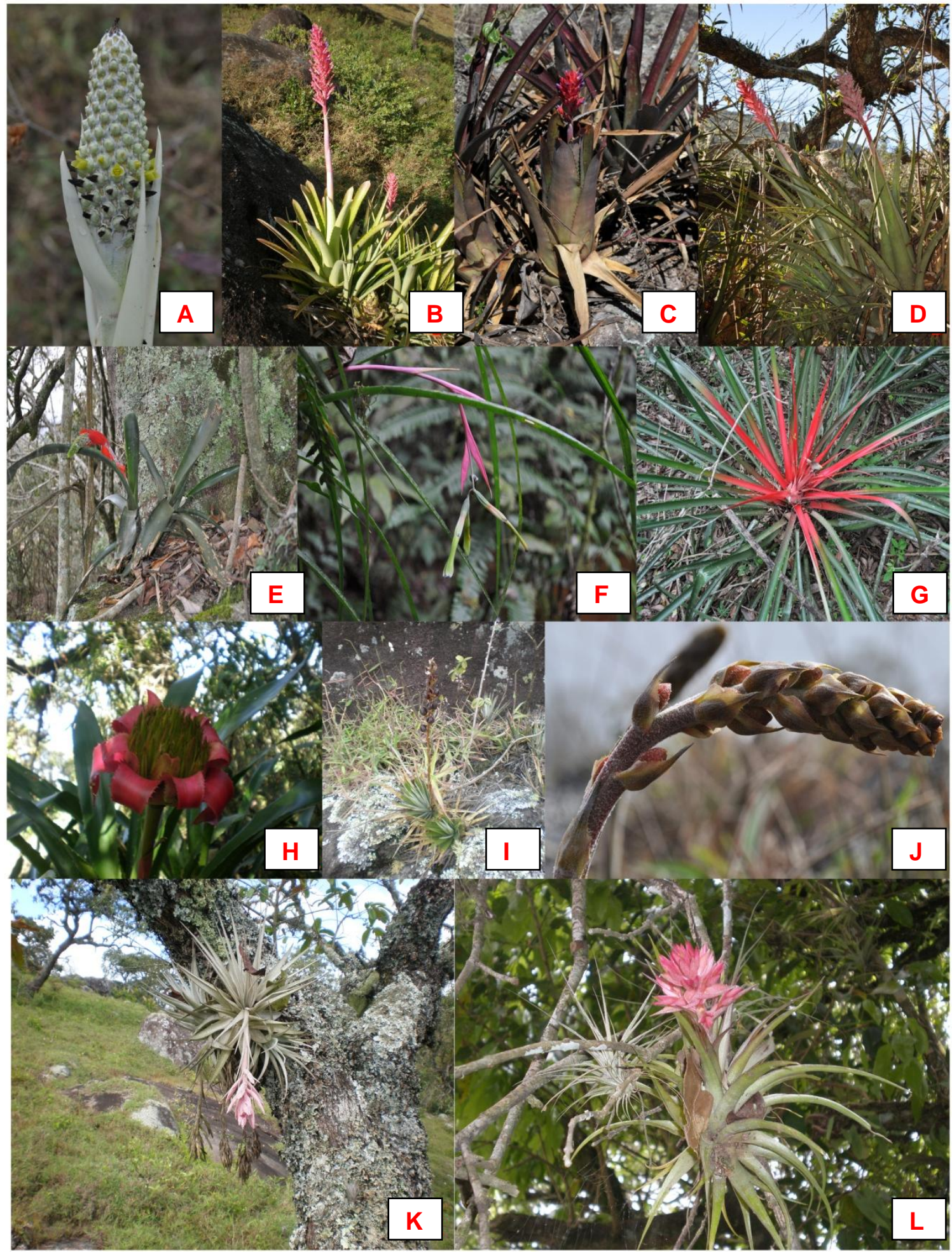

Fig. 3. A. Aechmea bromeliifolia var. albobracteata, inflorescência. B-D. A. distichantha, hábito e inflorescência. E. A. nudicaulis var. cuspidata, hábito. F. Billbergia distachia var. distachia, inflorescência. G. Bromelia regnellii, folhas. H. Wittrockia cyathiformis, inflorescência. I-J. Dyckia minarum, hábito e inflorescência jovem. K. Tillandsia gardneri, hábito e inflorescência. L. T. geminiflora, hábito e inflorescência. Fotos: A. Rosa, F. Moraes \& L. Heldt. 
Material examinado: Minas Gerais, Caldas, ASEPB, Pedra Branca, 2.VII.2009, A. E. M. Rosa, 86 (HRCB); 28.VIII.2009, A. E. M. Rosa 124 (HRCB); Pedra Branca,14.X.2009, A. E. M. Rosa 158 (HRCB); Pedra Branca, 17.XII.2009, A. E. M. Rosa 183 (HRCB); 12.IV.2010, A. E. M. Rosa 231 (HRCB); 16.VII.2010, A. E. M. Rosa 275 (HRCB); 30.VIII.2010, A. E. M. Rosa 304 (HRCB); 11.X.2010, A. E. M. Rosa 338 (HRCB); Pedra Branca, 20.X.2010, A. E. M. Rosa 358 (HRCB).

Material adicional: Minas Gerais, Poços de Caldas, 5.VII.1941, Viégas, A.P. s.n. (SP).

Aechmea distichantha ocorre no Paraguai, Argentina, Uruguai (Wanderley \& Martins 2007) e nas regiões Centro-Oeste, Sudeste e Sul do Brasil, em Cerrado e Mata Atlântica (Forzza et al. 2010). É uma das espécies mais comuns na ASEPB. É frequentemente encontrada como rupícola ou saxícola em áreas abertas, como Campos Rochosos e Campos de Altitude, e menos frequentemente como epífita em FESM, Cerradão e forófitos isolados dos Campos Rochosos. Na transição entre a FESA e Campos de Altitude, a espécie forma grandes adensamentos sobre a rocha nua, assim como em ambientes muito degradados: pastagem e áreas de mineração. A espécie apresentou-se muito polimórfica em relação à inflorescência e às folhas, motivo pelo qual não foram adotadas as variedades propostas por Smith e Downs (1979). Acredita-se que a presença de roseta tubular nos espécimes das regiões rochosas e de Campos de Altitude possa ser uma adaptação ao frio das altitudes elevadas. Estudos posteriores podem esclarecer a relação entre a disposição das folhas, o hábito e o papel ecológico da espécie nesta fisionomia. Floresce em praticamente todos os meses do ano. Borboletas e beija-flores foram vistos visitando suas flores.

3. Aechmea nudicaulis var. cuspidata Baker, J. Bot. 17: 234. 1879.

Fig. 3. E.

Epífita, rupícola ou saxícola, $54-76 \mathrm{~cm}$ alt. Roseta tubular. Folhas $32-67 \mathrm{~cm}$ compr., alternoespiraladas, congestas, pouco numerosas; bainha vinácea ou castanha, $16-34 \times 7,5-10 \mathrm{~cm}$, elíptica; lâmina verde a amarelada, $14-33 \times 3,5-6,7 \mathrm{~cm}$, ligulada, ápice agudo a obtuso, mucronado, com depressão na região proximal, margens espinescentes, espinhos castanho-escuros, 1-5 mm compr., antrorsos e retrorsos. Escapo avermelhado, (30-)41-57 cm compr., delgado, subereto, alvo-lanuginoso; brácteas escapais vermelhas, 5,3-9,5x1,1-2 cm, elípticas, ápice agudo a acuminado, lepidotas, densamente dispostas na base da inflorescência, margens inteiras. Inflorescência 6,4-18x2,5-3 cm de diâm., simples, cilíndrica, laxa ou densa, raque vermelha, alvolanuginosa, subereta; brácteas florais 1-4×0,5-1 mm, triangulares, ápice acuminado, mais curtas que as sépalas, margens inteiras, livres. Flores $1,5-2,0 \mathrm{~cm}$ compr., sésseis, polísticas; sépalas amareloesverdeadas, 6-10×3-4 mm, incluindo o múcron de 1-2 $\mathrm{mm}$, fortemente assimétricas, livres; pétalas amarelas,
8-11 $\times 2-3 \mathrm{~mm}$, espatuladas, eretas, ápice levemente recurvo, estames inclusos, filetes livres, anteras dorsifixas. Frutos alaranjados, subglobosos. Sementes ovóides.

Material examinado: Minas Gerais, Caldas, ASEPB, Pedra Branca, 23.VII.2009, A. E. M. Rosa 97 (HRCB); 29.VIII.2009, A. E. M. Rosa 134 (HRCB); 17.IX.2009, A. E. M. Rosa 146 (HRCB); Pedra Branca, 14/X/2009, A. E. M. Rosa 161 (HRCB); 16.VII.2010, A. E. M. Rosa 276 (HRCB); 31.VIII.2010, A. E. M. Rosa 320 (HRCB).

Material adicional: Minas Gerais, Caldas, 1.IX.1871, A. F. Regnell III, 1255 (S 139).

Aechmea nudicaulis var. cuspidata ocorre na Venezuela, Equador e nas regiões Sul e Sudeste do Brasil (Smith \& Downs 1979), em áreas limítrofes dos estados de Minas Gerais, Rio de Janeiro e São Paulo, na porção sul da Serra da Mantiqueira (Lima 2008). $\mathrm{Na}$ ASEPB, predomina a nordeste e sudeste, ao longo da Serra da Pedra Branca, entre 1100 e 1700m de altitude. Ocorre como epífita nas bordas das formações florestais (FESM e FESA), em forófitos isolados dos Campos Rochosos e sobre os arbustos entremeados às rochas expostas dos Campos de Altitude. Como rupícola, ocorre na transição entre FESA e Campos de Altitude, sobre rocha nua ou fendas que detenham umidade. Foi coletada com flores de junho a setembro, em frutificação em agosto e portando frutos maduros em outubro. Seus frutos alaranjados servem de alimento aos pássaros (Paula 1998), tendo sido observados na ASEPB espécimes com escapo totalmente nu após a frutificação.

4. Billbergia distachia var. distachia (Vell.) Mez in Mart., Eichler \& Urban, Fl. bras. 3(3): 417. 1892.

Fig. 3. F.

Epífita, saxícola ou rupícola, $40-80 \mathrm{~cm}$ alt. Roseta tubular. Folhas $34-87 \mathrm{~cm}$ compr., alternoespiraladas, congestas, pouco numerosas; bainha verde a vinácea, 3-17x1,7-4,7 cm, lanceolada a ovada, margens inteiras; lâmina verde, 30-70x1-2,2 cm, estreito-triangular, ápice acuminado, margens serrilhadas. Escapo róseo esverdeado, $34-58 \mathrm{~cm}$ compr., recurvo, glabro; brácteas escapais róseas, 8,5-15,7x1,1-1,9 cm, estreito-lanceoladas, ápice acuminado a apiculado, margens inteiras, alvolepidotas na face abaxial, eretas, membranáceas. Inflorescência esverdeada, 2,3-11 ×7-12 cm de diâm., simples, pêndula, glabra, eixo delicado e geniculado; brácteas florais 0,5-1(-5)x0,5-2 mm, inconspícuas a ovadas. Flores 4,7-6,7 cm compr., sésseis a curtopediceladas, zigomorfas na antese; sépalas esverdeadas a róseo-claras com mácula azul no ápice, 1,5-2,7x0,3-0,6 cm, oblongas, ápice obtuso a agudo ou emarginado, conatas na base; pétalas esverdeadas com mácula azul no ápice, 4-5x0,4-0,5 $\mathrm{cm}$, liguladas, eretas, ápice obtuso, recurvo na antese; filetes internos adnatos à base das pétalas, estames inclusos, anteras dorsifixas. Frutos subglobosos a ovóides. Sementes não vistas. 
Material examinado: Minas Gerais, Caldas, ASEPB, Pedra Branca, 2.VII.2009, A. E. M. Rosa 85 (HRCB); 28.VIII.2009, A. E. M. Rosa 122 (HRCB); 12.IV.2010, A. E. M. Rosa 233 (HRCB); Pedra do Coração, 3.V.2010, A. E. M. Rosa 247 (HRCB); 16.VII.2010, A. E. M. Rosa 281 (HRCB); Pedra Branca, 20.X.2010, A. E. M. Rosa 359 (HRCB).

Billbergia distachia var. distachia ocorre nos estados de RJ, MG, SP, PR e SC (Smith \& Downs 1979). Na ASEPB, é exclusiva de FESM, ocorrendo como epífita, saxícola ou rupícola em seu interior, borda e matas ciliares associadas, até a sua transição com a FESA, entre 1000 e 1600m, acompanhando a Serra da Pedra Branca. Ocorre nas áreas mais preservadas, montanhosas e úmidas da ASEPB. Observou-se grande variação quanto ao número de flores, de cerca de 4 a 10 nos indivíduos menores a até 23 nos maiores. Além disso, notou-se a grande quantidade de pólen produzida pela planta e, freqüentemente, sinais de herbivoria foram encontrados na região dos ovários. Esse fato associado ao florescimento de Billbergia distachia durante os meses de inverno, pode sugerir que a mesma tenha um importante papel como fonte de alimento para alguns animais. Billbergia distachia var. distachia floresce de abril a agosto e frutifica em outubro.

5. Bromelia regnellii Mez in Mart., Eichler \& Urban, Fl. bras. 3(3): 194. pl 53. 1891

Fig. 3. G.

Terrestre, cerca de 1,30 m alt. Roseta infundibuliforme. Folhas verdes, as centrais avermelhadas na fase reprodutiva, $2,17 \mathrm{~cm}$ compr., alterno-espiraladas, congestas; bainha coberta por escamas marrons, $7,2 \times 5,5 \mathrm{~cm}$, largo-elíptica, margens serrilhadas; lâmina $2,10 \times 1,7 \mathrm{~cm}$, linear-triangular, ápice pungente, margens com espinhos castanhos, 5 $6 \mathrm{~mm}$ compr., retrorsos na base e antrorsos para o ápice. Escapo cerca de $22 \mathrm{~cm}$ compr., brácteas escapais foliáceas, margens serrilhadas. Inflorescência $32 \times 17 \mathrm{~cm}$ de diâm., composta, raque ferrugínea, flores não vistas. Frutos imaturos $4 \mathrm{~cm}$. Sementes não vistas.

Material examinado: Minas Gerais, Caldas, ASEPB, 11.XII.2010, A. E. M. Rosa 374 (HRCB).

Material adicional: Minas Gerais, Caldas, sem data, A. F. Regnell II 285 (US 275006); 18.X.1869, A. F. Regnell II 285 (US 282451).

Bromelia regnellii ocorre em Minas Gerais e Goiás (Smith \& Downs 1979) em Cerrado e Mata Atlântica (Forzza et al. 2010). Na ASEPB, ocorre como terrestre, formando extensas colônias, em fragmentos de FESM e nos Cerradões, entre 1000 e 1500m de altitude. Está ausente nos Campos de Altitude e FESA. A espécie tem Caldas como localidade típica, tendo sido descrita com base em exsicatas de Regnell. De acordo com Smith e Downs (1979), floresce em novembro. No primeiro ano de coleta na
ASEPB, talvez pela existência de inverno atipicamente chuvoso, nenhum indivíduo fértil foi coletado. Em novembro e dezembro do ano seguinte, foram encontrados somente espécimes em frutificação. Apesar dos poucos registros para a espécie, Bromelia regnellii é bastante comum na ASEPB. Coletas posteriores na área de estudo e proximidades deverão ampliar os conhecimentos sobre sua distribuição.

6. Wittrockia cyathiformis (Vell.) Leme, Canistrum: Bromélias da Mata Atlântica. 67. 1997. Fig. 3. H.

Epífita, terrestre ou saxícola, $77-78 \mathrm{~cm}$ alt. Roseta infundibuliforme. Folhas $79-83 \mathrm{~cm}$ compr., alterno-espiraladas, congestas, bainha castanha, 15$17 \times 7,1-10,2 \mathrm{~cm}$, elíptica a obovada, margens inteiras a espinescentes no ápice, castanho lepidotas; lâmina verde, 53-67x3,3-3,5 cm, oblanceolada, ápice agudo a acuminado, mucronado, margens serrilhadas a espinescentes, espinhos castanho-escuros, 1-4 mm compr., antrorsos e retrorsos. Escapo castanhoesverdeado, 30-59 cm, igualando-se à altura das folhas, glabro; bráctea escapal rósea a vermelha, única, 9,1-10,7×2,9-3,3 cm, lanceolada, ápice acuminado, mucronado, próxima à base da inflorescência, margens serrilhadas, lepidotas. Inflorescência 8-9x7-8 cm diâm., composta, subcorimbosa; brácteas involucrais róseas a vermelhas, 2,3-3,5x9,5-10,2 cm, lanceoladas a ovadas, ápice reflexo, acuminado, mucronado, pálidolepidotas em ambas as faces, margens serrilhadas a espinescentes, espinhos castanhos, 1-3 mm compr.; brácteas primárias alvo-esverdeadas, semelhantes às involucrais, menores; fascículos com 5-7 flores, curtopedunculadas, pedúnculo $3-5 \mathrm{~mm}$, glabro; brácteas florais alvo-esverdeadas, 3,7-5,1 x0,3-0,4 cm, lineartriangulares, ápice acuminado, mucronado, mais curtas até igualando as sépalas, margens inteiras a serrilhadas, livres, glabras, carenadas. Flores 4-5,3 $\mathrm{cm}$ compr., sésseis, sépalas alvo-esverdeadas, 2,7$3,5 \times 0,4-0,5 \mathrm{~cm}$, estreito-triangulares, ápice acuminado, subsimétricas, livres, glabras, carenadas; pétalas não vistas. Frutos não vistos. Sementes não vistas.

Material examinado: Minas Gerais, Caldas, ASEPB, Pedra Branca, 20.VI.2010, A. E. M. Rosa 265 (HRCB); Pedra Branca, 20.VI.2010, A. E. M. Rosa 266 (HRCB); Pedra Branca, 20.VI.2010, A. E. M. Rosa 267 (HRCB).

Material adicional: Minas Gerais, Caldas, Pedra Branca, X.1861, A. F. Regnell III 1259 (S 905); III.1865, A. F. Regnell III 1259 (NY 873215).

Wittrockia cyathiformis ocorre na Bahia, Minas Gerais, Espírito Santo, Rio de Janeiro, São Paulo, Paraná e Santa Catarina, em Mata Atlântica (Forzza et al. 2010). Na ASEPB, é exclusiva de FESA, ocorrendo na Pedra Branca, acima de 1660m de altitude. Somente em seu ponto culminante, onde há água proveniente da neblina, foram encontrados espécimes em estágio reprodutivo e os maiores 
adensamentos de indivíduos. Provavelmente exceda os limites da ASEPB, ocorrendo nas regiões de relevo escarpado a sudeste da Pedra Branca, onde as condições ambientais são as mesmas. Smith e Downs (1979) citaram material de Regnell coletado em junho, na Pedra Branca. Durante este trabalho, os espécimes coletados no mesmo mês não apresentavam pétalas.

\section{Pitcairnioideae}

7. Dyckia minarum Mez in Mart., Eichler \& Urban, Fl. bras. 3(3): 483, pl. 91. 1894.

Fig. 3. I-J.

Terrestre ou saxícola, cerca de $42 \mathrm{~cm}$ alt. Roseta infundibuliforme. Folhas $8-15 \mathrm{~cm}$ compr., alterno-espiraladas, congestas; bainha castanho-clara, 2-2,5x3-3,5 cm, suborbicular, margens com diminutos espinhos próximos da transição com a lâmina, lepidota em direção ao ápice; lâmina cinérea, 6,6-13×0,5-0,9 $\mathrm{cm}$, estreito-triangular, ápice pungente, densamente lepidota na face abaxial, margens espinescentes, espinhos cerca de 0,5-1 $\mathrm{mm}$ compr., antrorsos. Escapo verde a castanho-avermelhado, $30-32 \mathrm{~cm}$ compr., lepidoto, ereto, axilar; brácteas escapais estramíneas, 2,3-3,1×1 cm, ovadas, ápice longoacuminado, lepidotas, excedendo os entrenós, margens serrilhadas. Inflorescência 13-20x3,2-3,5 cm de diâm., simples, laxa, raque glabra ou lepidota; brácteas florais estramíneas, 1,5-1,7×0,9-1,1 cm, ovadas, ápice longo-acuminado, patentes a reflexas na antese, semelhantes às do escapo, decorrentes, lepidotas, as proximais ultrapassando as flores, as distais igualando-as, carenadas, margens serrilhadas. Flores cerca de $2 \mathrm{~cm}$ compr, polísticas, patentes, pediceladas, pedicelo cerca de $3-5 \mathrm{~mm}$; sépalas alaranjadas a avermelhadas, 0,6-1,2×0,6-0,7 cm, ovadas, ápice agudo, esparsamente lepidotas, carenadas; pétalas alaranjadas, $1,4 \times 0,8 \mathrm{~cm}$, obtruladas, levemente carenadas, filetes conatos entre si até $1 / 2$ do comprimento, conatos cerca de $2 \mathrm{~mm}$ com as pétalas, formando anel pétalo-estamínico, estames inclusos, anteras dorsifixas. Frutos $1,8 \mathrm{~cm}$ compr. Sementes não vistas.

Material examinado: Minas Gerais, Caldas, ASEPB, Pedra Branca, 4.VI.2010, A. E. M. Rosa 260 (HRCB); Pedra Branca, 20.X.2010, A. E. M. Rosa 353 (HRCB).

Material adicional: Minas Gerais, Caldas, sem data, A. F. Regnell (NY 376596); 03.X.1862, A. F. Regnell II 283 (US 934758). Poços de Caldas, Cristo Redentor, 18.IX.1966, O. Roppa 860 (R). Paraná: Vila Velha, 17.XI.1964, E. Santos 2155 \& J. C. Sacco 2361 (R).

Dyckia minarum ocorre exclusivamente no Brasil, em Minas Gerais, Goiás, São Paulo (Smith \& Downs 1974, Forzza et al. 2010) e Paraná (material adicional), em Cerrado e Mata Atlântica (Forzza et al. 2010). É pouco frequente na ASEPB, estando restrita à primeira plataforma rochosa da Pedra Branca, a 1600m, nos Campos de Altitude. Geralmente cresce sobre pequena quantidade de material particulado oriundo da decomposição da rocha ou concorrendo com gramíneas que a encobrem quase totalmente na fase vegetativa. Foi descrita com base em coletas de Regnell em Caldas. Floresce em outubro e foi coletada com frutos secos, já sem sementes em junho. $\mathrm{Na}$ ASEPB, a população de Dyckia minarum merece atenção especial, já que é exclusiva da área mais acessível dos Campos de Altitude, onde sofre pressão antrópica e compete com gramíneas invasoras.

\section{Tillandsioideae}

\section{Tillandsia gardneri Lindl., Bot. Reg. 28: t. 63.} 1842.

Fig. 3. K.

Epífita ou rupícola, $18-26 \mathrm{~cm}$ alt.; caule inconspícuo. Folhas $12-20 \mathrm{~cm}$ compr., alternoespiraladas, congestas, as novas eretas, as senis reflexas, densamente lepidotas, escamas ultrapassando as margens da lâmina; bainha 0,61,1×1,1-1,6 cm, transversalmente elíptica; lâmina argêntea 10-19x0,8-1,2 cm, estreito-triangular, ápice longo-acuminado. Escapo verde, 11-15 cm compr., ereto a recurvo, encoberto pelas brácteas, não ultrapassando a roseta foliar, densamente lepidoto; brácteas escapais 4,1-5,3×0,8-1 cm, ovadas com ápice aristado, imbricadas, atingindo a inflorescência, densamente lepidotas, as proximais foliáceas. Inflorescência $5-7,7 \times 5-7 \mathrm{~cm}$ de diâm., composta, globosa, densa, ramificações de até $3^{\underline{a}}$ ordem, ramos curtos com cerca de 3-4 flora, não complanados, geniculados, apresentando ou não uma bráctea floral estéril no ápice dos ramos; brácteas primárias róseas, as proximais aristadas, semelhantes às do escapo; brácteas florais róseas, 1,5-1,9x0,6-0,8 cm, ovadas, ápice agudo, mais longas que as sépalas, carenadas, lepidotas. Flores cerca de $1,5 \mathrm{~cm}$ compr., polísticas; sépalas róseas, $0,9-1,2 \times 0,2-0,3 \mathrm{~cm}$, lanceoladas, ápice agudo, carenadas, lepidotas, as 2 posteriores curto-conatas; pétalas róseas a vermelhas, 1,1-1,5x0,2 $\mathrm{cm}$, liguladas, ápice obtuso; estames livres, inclusos, filetes plicados, anteras dorsifixas. Frutos com até 3,5 $\mathrm{cm}$. Sementes não vistas.

Material examinado: Minas Gerais, Caldas, ASEPB, Pedra Branca, 17.XII.2009, A. E. M. Rosa 178 (HRCB); 17.XII.2009, A. E. M. 191 (HRCB); 13.IV.2010, A. E. M. Rosa 239 (HRCB); ASEPB, 13.IV.2010, A. E. M. Rosa 240 (HRCB); 16.VII.2010, A. E. M. Rosa 278 (HRCB).

Material adicional: Minas Gerais, Caldas, Pedra Branca, 11.V.1931, Ostermeyer, R. s.n. (SP); 23.IX.1798, A. F. Regnell III 1798 (US 204810).

Tillandsia gardneri ocorre na Colômbia, Venezuela e Brasil (Wanderley \& Martins 2007), em todos os estados das regiões Sudeste e Sul e nos estados do PI, CE, PB, BA, AL, SE, no Nordeste, em 
Mata Atlântica, Caatinga e Cerrado (Forzza et al. 2010). Na ASEPB, ocorre nos Campos de Altitude da Pedra Branca, a $1500 \mathrm{~m}$, exclusivamente como rupícola, e nos Campos Rochosos, a cerca de 1300m de altitude, como epífita. No Parque Estadual da Serra do Rola-Moça, a espécie é epífita nas Florestas Estacionais Semideciduais, geralmente em áreas abertas, e nos capões de mata dos Campos Rupestres Ferruginosos (Guarçoni et al. 2010). Apesar da proximidade entre Tillandsia gardneri e $T$. geminiflora, as duas espécies são facilmente distintas na ASEPB, tanto pelos aspectos morfológicos quanto pelo habitat. As sépalas de T. gardneri foram descritas como sendo livres por Wanderley e Martins (2007), Paula (1998) e Coffani-Nunes et al. (2010), diferindo do que foi observado neste trabalho. Aqui, verificou-se uma discreta conação das duas sépalas posteriores. $\mathrm{Na}$ ASEPB, há dois picos de floração para a espécie: um entre abril e maio; outro em dezembro. Foram coletados indivíduos com frutos imaturos em julho e com frutos secos em abril.

9. Tillandsia geminiflora Brongn. in Duperrey, Voy. Coquille 186. 1829.

Fig. 3. L.

Epífita, 16-24 cm alt.; caule inconspícuo. Folhas $10-19 \mathrm{~cm}$ compr., alterno-espiraladas, congestas, lepidotas, as jovens eretas, as senis reflexas; bainha pouco distinta; lâmina verde, 9$18 \times 0,6-1,1 \mathrm{~cm}$, estreito-triangular, ápice longoacuminado. Escapo esverdeado 6-12 cm compr., ereto a levemente recurvo, glabro a esparsamente lepidoto, não ultrapassando a roseta; brácteas escapais verdes, 3,1-6,3×0,7-1 cm, ovadas com ápice aristado, lepidotas, mais ou menos laxas, às vezes deixando escapo evidente, as proximais foliáceas. Inflorescência 3,8-6x3-5,5 cm diâm., composta, piramidal, geralmente densa, com ramificações de $2^{a}$ ordem, ramos curtos não complanados, geniculados, 2-3 flores e um botão floral estéril por ramo; brácteas primárias vermelhas, ovadas, semelhantes às do escapo; brácteas florais vermelhas, 0,8-1,3×0,25-0,6 $\mathrm{cm}$, ovadas, ápice agudo a acuminado, carenadas, mais curtas que as sépalas, lepidotas. Flores 1,3-1,5 cm compr., polísticas; sépalas róseas, 0,9-1,4×0,15$0,2 \mathrm{~cm}$, lanceoladas, ápice agudo a acuminado, as 2 posteriores curto-conatas, carenadas, glabras ou lepidotas; pétalas róseo-escuras a vermelhas, 1,11,6x0,15-0,2 cm, espatuladas, ápice obtuso, estames livres, inclusos, filetes plicados, anteras dorsifixas. Frutos cerca de 3,3 cm compr. Sementes não vistas.

Material examinado: Minas Gerais, Caldas, ASEPB, 17.IX.2009, A. E. M. Rosa 143 (HRCB); 13.I.2010, A. E. M. Rosa 202 (HRCB); 30.VIII.2010, A. E. M. Rosa 310 (HRCB); 13.XII.2010, A. E. M. Rosa 391 (HRCB).

Tillandsia geminiflora ocorre no Paraguai e Argentina e nas regiões Centro-Oeste, Sudeste, Sul (Wanderley \& Martins 2007) e Nordeste do Brasil
(Martinelli et al. 2008), em Cerrado e Mata Atlântica (Forzza et al. 2010). Na ASEPB, é exclusivamente epífita no interior dos Cerradões e em matas ciliares ou próximas a elas em FESM. É bastante incomum na área de estudo, sendo encontrados indivíduos isolados nas cotas entre 1100 e $1400 \mathrm{~m}$. Floresce em agosto e setembro e foi coletada com frutos imaturos em dezembro. Coffani-Nunes et al. (2010) relataram a presença de dois picos de floração na Serra do Cipó: um em junho e outro em novembro.

10. Tillandsia pohliana Mez in Mart., Eichler \& Urban, Fl. bras. 3(3): 597. 1894.

Fig. 4. A.

Epífita, 21-34 cm alt.; caule inconspícuo. Folhas 16-27 cm compr., alterno-espiraladas, congestas, eretas a suberetas, lepidotas; bainha 0,61,3×1,3-2 cm, transversalmente elíptica; lâmina cinérea, 15-26x0,5-0,8 cm, estreito-triangular, ápice acuminado, conduplicada. Escapo esverdeado, 11-20 cm compr., não ultrapassando a roseta foliar, ereto a levemente recurvo, lepidoto, brácteas escapais esverdeadas, 5,3-9,8(-12)x1,1-1,6 cm, ovadas a elípticas, ápice aristado, ultrapassando os entrenós, imbricadas, densamente lepidotas, as proximais foliáceas. Inflorescência 3-6,7(-11)x4-5 cm diâm., simples, cilíndrica, densa ou subdensa, raque lepidota; brácteas florais alvo-esverdeadas a levemente castanho-alaranjadas, 2-3(3,7) X1,2-2 cm, elípticas a largo-elípticas, ápice agudo e apiculado nas distais, ápice aristado nas proximais, em geral completamente lepidotas, ultrapassando as sépalas. Flores 2-2,2 cm compr., polísticas; sépalas verdes, 1,2-1,5(-1,8)x0,8-1 $\mathrm{cm}$, elípticas a largo-elípticas, ápice agudo, coriáceas, livres, densamente lepidotas; pétalas alvas, 1,9-2,2($2,5) \times 0,2-0,3 \mathrm{~cm}$, espatuladas, ápice obtuso; estames livres, inclusos, filetes plicados, anteras basifixas. Frutos 4,5-5 cm compr. Sementes não vistas.

Material examinado: Minas Gerais: Caldas, ASEPB, 28.VIII.2009, Rosa, A.E.M. 121 (HRCB); 13.I.2010, A. E. M. Rosa 199 (HRCB); 3/V/2010, A. E. M. Rosa 244 (HRCB); 30.VIII.2010, A. E. M. 299 (HRCB); 11.X.2010, A. E. M. Rosa 344 (HRCB); 13.XI.2010, A. E. M. Rosa 370 (HRCB); 11.XII.2010, A. E. M. Rosa 383 (HRCB).

Tillandsia pohliana ocorre no sul do Peru, na Bolívia, Paraguai, norte da Argentina (Smith \& Downs 1977), nas regiões Nordeste (PB, PE), Centro-Oeste (MT, MS. GO, DF), Sudeste (MG, SP) e Sul (PR) do Brasil, em Caatinga, Cerrado e Mata Atlântica (Forzza et al. 2010). Na ASEPB, é exclusivamente epífita, em Cerradão, FESM, Campos Rochosos e áreas antropizadas, geralmente em altitudes entre 1000 e $1400 \mathrm{~m}$. É mais comum entre a região central e o sudoeste da ASEPB. Apesar de ser comum, não havia registros de sua ocorrência na região até o presente momento (Smith \& Downs 1977, Versieux \& Wendt 2006). Este fato pode estar associado à ausência de 


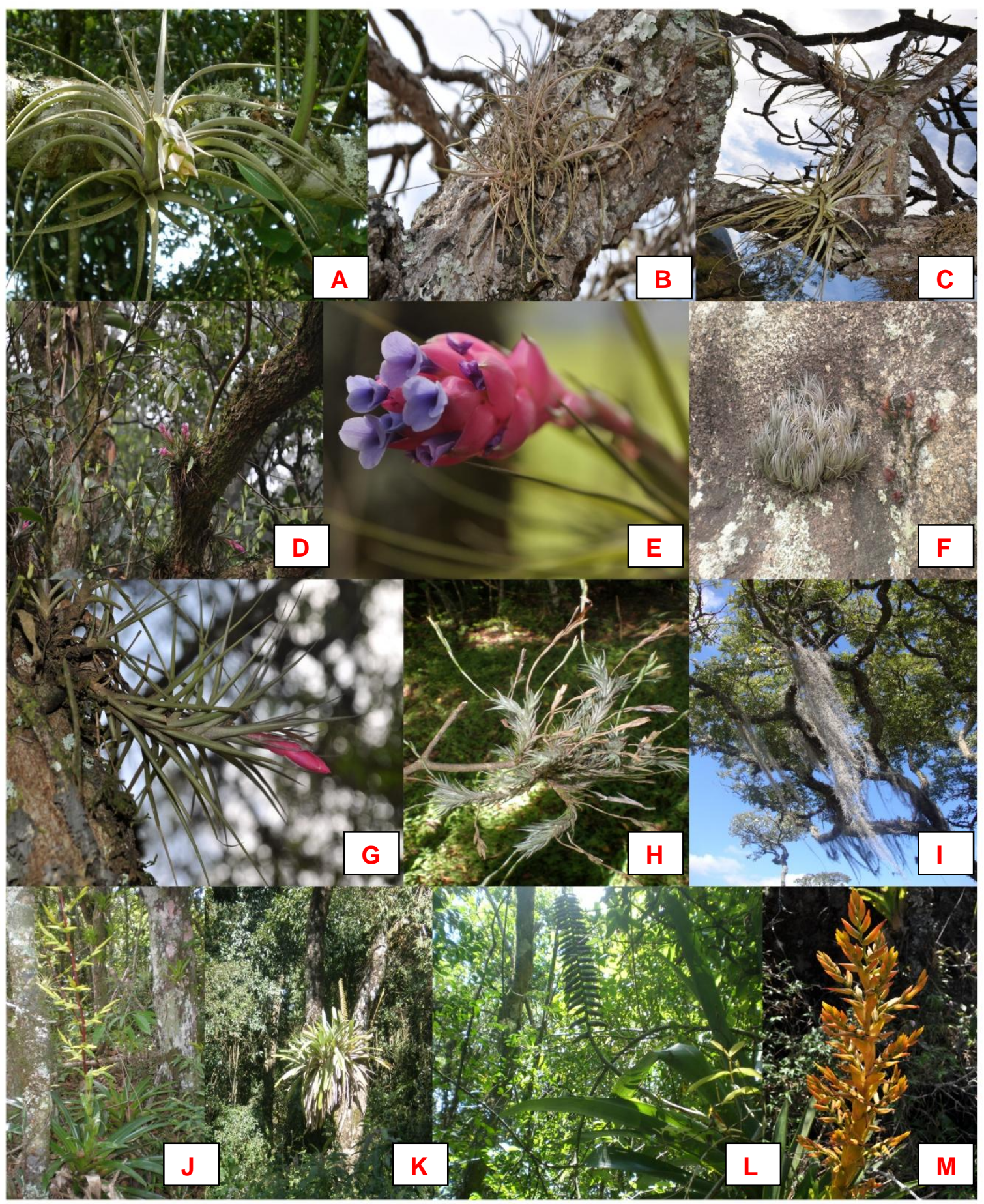

Fig. 4. A. Tillandsia pohliana, hábito. B. T. recurvata, hábito. C. T. streptocarpa, hábito. D-E. T. stricta var. stricta, hábito, inflorescência e flor. F-G. T. tenuifolia, hábito e inflorescência. H. T. tricholepis var. tricholepis, hábito e inflorescência. I. T. usneoides, hábito. J. Vriesea friburgensis var. tucumanensis, inflorescência. K-L. V. regnellii, hábito e inflorescência. M. V. sceptrum, inflorescência. Fotos: A. Rosa \& L. Heldt. 
expedições de Regnell aos locais mais distantes da Serra da Pedra Branca, que hoje compõem o interior e as faces noroeste e sudoeste da ASEPB. Ou ainda, o relevo mais aplainado destes locais privilegiou ações antrópicas, fazendo com que houvesse alterações na composição florística da área. As quatro espécies com novas ocorrências ( $T$. pohliana, $T$. recurvata, $T$. streptocarpa e $T$. tricholepis) são heliófitas e habitam áreas abertas, podendo ter sido favorecidas pela supressão da vegetação original. Com exceção de $T$. pohliana, todas as outras espécies de Tillandsia tratadas neste trabalho foram encontradas por CoffaniNunes et al. (2010) para a Serra do Cipó. Na ASEPB, $T$. pohliana floresce entre outubro e janeiro. Foi coletada com frutos em outubro.

11. Tillandsia recurvata (L.) L., Sp. Pl. Ed. 2. 410. 1762.

Fig. 4. B.

Epífita, raramente rupícola, $7,5-14 \mathrm{~cm}$ alt., formando touceiras; caule inconspícuo. Folhas 3,5-10 cm compr., poucas, alterno-dísticas, laxamente dispostas ao longo do caule, recurvas, densamente lepidotas; bainha 1,2-1,4×0,5-0,6 cm, elíptico-ovada; lâmina cinérea a verde, 2,5-8 $\times 0,5-1 \mathrm{~mm}$, linear, subcilíndrica, sulcada na base, involuta. Escapo esverdeado, 3,7-9 cm compr., ultrapassando as folhas; bráctea escapal única, 7-9,5(-14)×2,5-3 mm, ovada a lanceolada, geralmente aristada, na base da inflorescência, lepidota. Inflorescência 1-2-flora, 0,7$1,5 \times 0,2-0,4 \mathrm{~cm}$, simples; brácteas florais verdeacinzentadas, 6-8 $\times 2-3 \mathrm{~mm}$, ovadas, ápice acuminado, lepidotas, semelhantes à do escapo. Flores cerca de 1,1 cm compr., dísticas; sépalas verdes, 5,5-7x1-2 $\mathrm{mm}$, livres, lanceoladas, ápice agudo, glabras; pétalas lilás, 6-8x1 mm, liguladas, ápice obtuso; estames livres, inclusos, filetes retos, anteras dorsifixas. Frutos 1-3 cm compr. Sementes não vistas.

Material examinado: Minas Gerais, Caldas, ASEPB, 9.VII.2009, A. E. M. Rosa 95 (HRCB); 14.X.2009, A. E. M. Rosa 153 (HRCB); 13.I.2010, Rosa, A.E.M. 193 (HRCB); Pedra do Coração, 22.I.2010, A. E. M. Rosa 213 (HRCB); 12.IV.2010, A. E. M. Rosa 237 (HRCB); 30.VIII.2010, A. E. M. Rosa 293 (HRCB).

Tillandsia recurvata ocorre dos Estados Unidos até a Argentina (Smith \& Downs 1977) e em todo o Brasil (Wanderley \& Martins 2007), em Caatinga, Cerrado e Mata Atlântica (Forzza et al. 2010). Na ASEPB, é frequente em todas as formações vegetais, entre 1100 e $1550 \mathrm{~m}$ de altitude, mais comumente como epífita. Habita áreas antropizadas, árvores isoladas na transição entre Mata e Campos de Altitude e Campos Rochosos, assim como relatado por Paula (1998) para o Parque Estadual da Serra do Brigadeiro. Segundo Smith e Downs (1977) e Versieux e Wendt (2006), a espécie não foi coletada por Regnell (comentários em T. pohliana). Indivíduos em floração foram coletados em dezembro e janeiro, e portando frutos secos durante a maior parte do ano.

12. Tillandsia streptocarpa Baker, Jour. Bot. London 25: 241. 1887.

Fig. 4. C.

Epífita ou rupícola, 21-51 cm alt.; caule conspícuo. Folhas $12,5-32 \mathrm{~cm}$ compr., alternoespiraladas, congestas, suberetas com ápice fortemente recurvo, lepidotas; bainha castanho-clara, 2,2-3x1,6-2,5 cm, ovóide, lepidota em direção ao ápice na face abaxial; lâmina cinérea, 10,5-30x0,3-1 cm, linear-triangular, involuto-subulada, ápice longoatenuado. Escapo castanho, $12-33 \mathrm{~cm}$, ereto, ultrapassando as folhas, glabro; brácteas escapais 3,5-7,8 $\times 0,5-1,1 \mathrm{~cm}$, lanceoladas, ápice aristado nas proximais e apiculado nas distais, conduplicadas, imbricadas, amplectivas, lepidotas, as proximais foliáceas. Inflorescência 5-15,5x5-15 cm, laxa, simples ou composta, com ramificações de até $3^{\text {a }}$ ordem, ramos complanados; brácteas primárias semelhantes às do escapo, algumas carenadas, nervadas; brácteas florais páleo-esverdeadas, 11,5x0,4-0,6 cm, lanceoladas, ápice agudo, carenadas ou não, esparsamente lepidotas a glabras, subigualando a igualando as sépalas. Flores 1,6-2,6 cm compr., dísticas, aromáticas; sépalas verdearroxeadas, $1-1,4 \times 0,4 \mathrm{~cm}$, obtruladas, ápice agudo a obtuso, livres, glabras; pétalas lilás, 2-2,5x0,9-1,1 cm, espatuladas, ápice obtuso; estames livres, inclusos, filetes levemente plicados próximo às anteras, anteras dorsifixas. Frutos $3-4,5 \mathrm{~cm}$ compr. Sementes não vistas.

Material examinado: Minas Gerais, Caldas, ASEPB, 28.VIII.2009, A. E. M. Rosa 119 (HRCB); 29.VIII.2009, A. E. M. Rosa 128 (HRCB); 13.I.2010, A. E. M. Rosa 197 (HRCB); Pedra do Coração, 22.I.2010, A. E. M. Rosa 212 (HRCB); 16.VII.2010, A. E. M. Rosa 272 (HRCB); 30.VIII.2010, A. E. M. Rosa 317 (HRCB); 11.X.2010, A. E. M. Rosa 331 (HRCB); 13.XI.2010, A. E. M. Rosa 366 (HRCB).

Tillandsia streptocarpa ocorre no Peru, Bolívia, Paraguai e Brasil, nos estados de PE, PB, BA, GO, MG, SP, PR, RS e DF (Smith \& Downs 1977), além de MS, MT, PI, RN (Versieux \& Wendt 2006), em Caatinga, Cerrado e Mata Atlântica (Forzza et al. 2010). Na ASEPB, é geralmente epífita, ocorrendo nos Campos Rochosos em regeneração, em forófitos isolados em meio à pastagem ou em beiras de estradas. É mais comum nos Campos Rochosos localizados na base da Serra da Pedra Branca e na face noroeste da ASEPB. Tillandsia streptocarpa apresentou grande polimorfia em relação à inflorescência: em alguns indivíduos a inflorescência é simples, com poucas flores, enquanto em outros ela é composta, com muitas flores. O presente trabalho cita pela primeira vez a ocorrência de $T$. streptocarpa em Caldas (comentários em T. pohliana). A espécie não foi coletada por Regnell, mas há registros de sua 
ocorrência em Andradas (Smith \& Downs 1977), município vizinho a noroeste da área de estudo. $T$. streptocarpa floresce de outubro a janeiro. Foram coletados indivíduos com frutos imaturos em janeiro e com frutos secos em julho e agosto.

13. Tillandsia stricta var. stricta Sol. in Sims, Bot. Mag. 37: t. 1529. 1813.

Fig. 4. D-E.

Epífita ou rupícola, $12-20 \mathrm{~cm}$ alt.; caule inconspícuo. Folhas 6,5-19 cm compr., alternoespiraladas, congestas, eretas, as senis patentes a reflexas, às vezes secundas, lepidotas; bainha castanho-clara $0,5-0,9 \times 1-1,2 \mathrm{~cm}$, transversalmente elíptica; lâmina verde a cinérea, $6-17,5 \times 0,2-0,5 \mathrm{~cm}$, estreito-triangular, ápice longo-acuminado. Escapo 6$9(-11) \mathrm{cm}$, ereto a levemente recurvo; brácteas escapais róseas, 2,7-8,2x0,8-1,2 cm, ovadas a elípticas, ápice aristado, imbricadas, as proximais foliáceas, lepidotas. Inflorescência 2,7-7,5×2-3 cm de diâm., globosa a subglobosa, geralmente densa, simples; brácteas florais róseas, alvo-esverdeadas na senescência, 1,0-2,6x0,9-1,4 cm, elípticas, as proximais com ápice longo-aristado, as distais com ápice agudo, apiculado, em geral lepidotas apenas no ápice, ultrapassando as sépalas. Flores 1,5-2 cm compr., polísticas; sépalas róseo-claras, 0,7-1,3×0,3 $\mathrm{cm}$, lanceoladas a ovadas, ápice agudo a acuminado, membranáceas, carenadas, curto-conatas, glabras; pétalas roxas a róseo-escuras, 1,2-2,1x0,2-0,3 cm, espatuladas, ápice obtuso; estames livres, inclusos, filetes plicados, anteras basifixas. Frutos $3,8 \mathrm{~cm}$ compr. Sementes cerca de $3 \mathrm{~cm}$.

Material examinado: Minas Gerais, Caldas, ASEPB, Pedra Branca, 2.VII.2009, A. E. M. Rosa 83 (HRCB); 29.VIII.2009, A. E. M. Rosa 138 (HRCB); 22.II.2010, A. E. M. Rosa 226 (HRCB); Pedra Branca, 26.V.2010, A. E. M. Rosa 252 (HRCB); 30.VIII.2010, A. E. M. Rosa 292 (HRCB); 31.VIII.2010, A. E. M. Rosa 321 (HRCB); 11.X.2010, A. E. M. Rosa 343 (HRCB); 13.XI.2010, A. E. M. Rosa 362 (HRCB); 11.XII.2010, A. E. M. Rosa 384 (HRCB).

Tillandsia stricta var. stricta ocorre na Venezuela, Trinidad, Guiana, Suriname, Paraguai, Uruguai, norte da Argentina e no Brasil (Smith \& Downs 1977), no Centro-Oeste e Sudeste e parte do Sul (PR, RS) e do Nordeste (CE, PB, PE, BA, AL, SE), em Cerrado e Mata Atlântica (Forzza et al. 2010). Apresenta ampla distribuição na ASEPB, sendo encontrada em todas as formações vegetais. É frequentemente epífita, mas pode ocorrer como rupícola nos afloramentos rochosos dos Campos de Altitude. Coffani-Nunes et al. (2010) só encontram indivíduos epífitos para a Serra do Cipó. Indivíduos com características intermediárias entre $T$. stricta e $T$. tenuifolia foram vistos nos locais onde as espécies são simpátricas. O pico de floração de T. stricta var. stricta variou entre outubro e dezembro, embora tenham sido coletados indivíduos em florescimento em janeiro e de abril a setembro. Indivíduos com cápsulas abertas e contendo sementes foram coletados em abril, maio e agosto.

14. Tillandsia tenuifolia L., Sp. PI. 286. 1753. Fig. 4. F-G.

Epífita, rupícola ou saxícola, 9-20 cm alt.; caule inconspícuo a bem desenvolvido, ramificado ou não. Folhas 4-15 cm compr., alterno-espiraladas, congestas ou laxamente dispostas ao longo do caule, eretas, suberetas ou patentes, às vezes secundas; bainha $0,5-0,6 \times 0,6-1,5 \mathrm{~cm}$, transversalmente elíptica; lâmina verde, 3,3-14×1,5-4 mm, estreito-triangular a linear-triangular, subulada para o ápice, conduplicada. Escapo esverdeado, 2-9,5 cm compr., ereto a levemente recurvo; brácteas escapais róseas a esverdeadas, 1,4-4,7×0,6-0,9cm, elípticas, ápice aristado, imbricadas, lepidotas, as proximais foliáceas. Inflorescência 2-3,5x1,5-3 cm de diâm., simples, ovóide a cilíndrica, subdensa, podendo apresentar um botão floral atrofiado no ápice; brácteas florais róseoclaras a róseo-escuras, 1,3-2,4×0,5-0,9 cm, elípticas, ápice agudo, apiculado, nervadas, carenadas, glabras ou lepidotas em direção ao ápice, ultrapassando as sépalas. Flores 1,6-1,7 cm compr., polísticas; sépalas róseo-claras a róseo-escuras, 0,9-1,6x0,2 cm, lanceoladas, ápice agudo, livres ou as duas posteriores curto-conatas ou conatas até a metade, carenadas, membranáceas, glabras; pétalas alvas, róseas ou roxas, 1,3-2,0x0,2-0,3 cm, espatuladas, ápice obtuso; estames inclusos, filetes internos adnatos à base das pétalas, fortemente plicados, anteras basifixas. Frutos cerca de $1,5 \mathrm{~cm}$ compr. Sementes não vistas.

Material examinado: Minas Gerais, Caldas, ASEPB, 17.IX.2009, A. E. M. Rosa 144 (HRCB); 22.I.2010, A. E. M. Rosa 210 (HRCB); Pedra Branca, 20.VI.2010, A. E. M. Rosa 264 (HRCB); Pedra Branca, 3.VIII.2010, A. E. M. Rosa 289 (HRCB); 11.X.2010, A. E. M. Rosa 342 (HRCB); 11.XII.2010, A. E. M. Rosa 375 (HRCB); 13.XII.2010, A. E. M. Rosa 392 (HRCB).

Material adicional: Minas Gerais: Caldas, 20.XI.1930, Hoehne, F.C. s.n. (SP).

Tillandsia tenuifolia ocorre na Venezuela, em Trinidad, na Guiana, no Suriname, Paraguai, Uruguai e norte da Argentina (Smith \& Downs 1977). No Brasil ocorre em quase todos os estados litorâneos, além do Centro-Oeste (Wanderley \& Martins 2007), na Amazônia, Caatinga, Cerrado e Mata Atlântica (Forzza et al. 2010). Na ASEPB, é encontrada nas bordas de FESM e nos Campos de Altitude, entre 1100 e 1750m. Quando é saxícola ou rupícola, habita os Campos de Altitude; quando é epífita, habita as bordas ou o terço superior das árvores mais altas da FESM, geralmente formando grandes adensamentos. $\mathrm{Na}$ transição entre Mata e Campos de Altitude foram vistos alguns indivíduos epífitos que permaneceram em estágio vegetativo durante a execução dos trabalhos. Tentou- 
se relacionar o grau de conação das sépalas, o hábito, a morfologia foliar e coloração das pétalas para identificação das variedades citadas para Caldas (Smith \& Downs 1977), mas a sobreposição dos caracteres diagnósticos não permitiu a adoção desta categoria taxonômica. Para as $T$. tenuifolia da ASEPB há dois picos de floração relacionados à fisionomia: espécimes de Campos de Altitude florescem entre junho e agosto; espécimes de FESM, entre outubro e dezembro.

15. Tillandsia tricholepis Baker, Jour. Bot. London 16: 237. 1878.

Fig. 4. $\mathrm{H}$.

Epífita, 4-10 cm alt.; caule conspícuo. Folhas 1,1-1,5 cm compr., alterno-espiraladas, laxamente dispostas ao longo do caule, eretas a suberetas, densamente lepidotas; bainha castanho-clara, 0,3$0,4 \times 0,2-0,3 \mathrm{~cm}$, largo-oval; lâmina ferrugínea ou cinérea, 0,7-1,3×1 cm, estreito-triangular, involuta. Escapo cinéreo, 3-4 cm compr., ultrapassando as folhas, ereto, não completamente envolvido pelas brácteas; brácteas escapais 0,8-1x0,25-0,3 cm, lanceoladas, ápice agudo, amplectivas, mais curtas a ultrapassando os entrenós, lepidotas. Inflorescência 1,7-3x0,7-1 cm, simples, raque ereta a levemente geniculada, glabra; brácteas florais verdeacinzentadas, 0,7-0,9×0,4 cm, ovadas, ápice agudo, subigualando as sépalas, lepidotas. Flores $1 \mathrm{~cm}$ compr., dísticas; sépalas verdes, $0,7 \times 0,1 \mathrm{~cm}$, lanceoladas, ápice agudo, livres, glabras; pétalas amarelas, 0,8×0,1 cm, liguladas, ápice agudo; estames inclusos, livres, filetes retos, anteras basifixas. Frutos 1,9-2,1 cm compr. Sementes não vistas.

Material examinado: Minas Gerais, Caldas, ASEPB, 13.II.2010, A. E. M. Rosa 201 (HRCB); 22.II.2010, A. E. M. Rosa 218 (HRCB); 12.IV.2010, A. E. M. Rosa 232 (HRCB); 16.VII.2010, A. E. M. Rosa 277 (HRCB); 30.VIII.2010, A. E. M. Rosa 306 (HRCB); 13.XI.2010, A. E. M. Rosa 361 (HRCB).

Material adicional: São Paulo, Bauru, 21.V.1993, $P$ M. Souza 7 (SP). Botucatu, VIII.2009, L. B. Santos 143 (HRCB). Brotas, 25///2007, S. A. Nicolau 3144 et al. (SP).

Tillandsia tricholepis ocorre na Bolívia, Paraguai, Argentina e Brasil (Smith \& Downs 1977), no CE, PB, PE, MG, RJ, PR, RS (Forzza et al. 2010) e SP (material adicional), em Caatinga, Cerrado e Mata Atlântica (Forzza et al. 2010). Na ASEPB, é epífita em áreas abertas antropizadas, Campos Rochosos e FESM, entre 1100 e 1350 m de altitude. Mesmo não sendo abundante, apresenta ampla distribuição. Araucaria angustifolia (Bertol.) Kuntze lhe serviu de forófito em algumas das ocorrências. O fato da espécie não ter sido coletada por Regnell (Smith \& Downs 1977, Versieux \& Wendt 2006) pode estar associado ao pequeno porte dos indivíduos ou à dificuldade de sua observação no estrato superior das árvores mais altas, onde possivelmente viveria, sob luz direta. Após a supressão da vegetação original, a espécie pode ter conquistado condições de insolação ideais e colonizado outros locais da ASEPB. Foi coletada com flores em dezembro e janeiro e portando frutos secos em abril e agosto.

16. Tillandsia usneoides (L.) L., Sp. Pl. ed. 2. 411. 1762 .

Fig. 4. I.

Epífita, 3-7 cm alt., pendente nos ramos das árvores; caule linear, foliáceo, com entrenós de 1-6 $\mathrm{cm}$; raízes ausentes na fase adulta. Folhas cinéreas, 2-6 cm compr., poucas, alterno-dísticas, laxamente dispostas ao longo do caule, patentes, lepidotas; bainha castanha, $8-10 \times 2,5 \mathrm{~mm}$, elíptica, amplectiva; lâmina cinérea, 3-5,5x0,5 cm, linear, involuta. Escapo curto, praticamente ausente. Inflorescência uniflora, cerca de 1,5 cm compr.; brácteas florais paleáceas, $4 \times 2,5 \mathrm{~mm}$, elípticas, ápice mucronado, na base da inflorescência, menores que as sépalas, lepidotas. Flores únicas, sépalas $7 \times 1,5 \mathrm{~mm}$, lanceoladas, ápice agudo, conatas na base, lepidotas; pétalas não vistas. Frutos cerca de $2,5 \mathrm{~cm}$. Sementes não vistas.

Material examinado: Minas Gerais, Caldas, ASEPB, 17.IX.2009, A. E. M. Rosa 148 (HRCB); 14.X.2009, A. E. M. Rosa 150 (HRCB); 13.II.2010, A. E. M. Rosa 208 (HRCB); Pedra do Coração, 22.I.2010, A. E. M. Rosa 214 (HRCB); 3.V.2010, A. E. M. Rosa 245 (HRCB); 16.VII.2010, A. E. M. Rosa 280 (HRCB); 31.VIII.2010, A. E. M. Rosa 326 (HRCB).

Tillandsia usneoides ocorre do sudeste dos Estados Unidos até o centro da Argentina e Chile (Smith \& Downs 1977). No Brasil, ocorre em MG e nos estados litorâneos (do PI ao RS), em Caatinga, Cerrado e Mata Atlântica (Forzza et al. 2010). Na ASEPB, cresce em forófitos localizados nas bordas ou próximos à $\mathrm{FESM}$, e em árvores isoladas nos Campos Rochosos, entre 1100 e 1550m de altitude. Sua ocorrência coincide com locais onde houve intervenção humana. Não foi vista portando flores; somente frutos secos, em agosto.

17. Vriesea friburgensis var. tucumanensis (Mez) L.B. Sm., Anais Bot. Herb. "Barbosa Rodrigues" 4: 68. 1952.

Fig. 4. J.

Epífita ou terrestre, 0,66-1,26 m alt. Roseta infundibuliforme. Folhas $22-56 \mathrm{~cm}$ compr., alternoespiraladas, congestas, bainha castanha na base da face abaxial e castanha a vinácea na face adaxial, 8$17 \times 5,3-9 \mathrm{~cm}$, elíptica; lâmina verde a amarelada, 13,5$39 \times 2,6-3,7(-4,8) \mathrm{cm}$, triangular, ápice agudo $\mathrm{e}$ mucronado. Escapo vinoso, $32-72 \mathrm{~cm}$ compr., glabro, ereto; brácteas escapais proximais foliáceas, as distais 4,3-10x1,7-2,5 cm, triangulares a estreito-triangulares, ápice agudo e mucronado, imbricadas, amplectivas. Inflorescência 22-63×11-15 cm diâm., composta, em 
racemo heterotético duplo, ereta, laxa; ramos 3-11, fracamente geniculados, suberetos com entrenós 0,9 $1,4 \mathrm{~cm}$, flores $5-8$, pedúnculos $0,5-1 \mathrm{~cm}$, com ou sem brácteas estéreis; brácteas primárias amareladas a verde-vinosas, mais longas que o pedúnculo, as proximais semelhantes às do escapo, as distais 3,24,2x1,9-2,4 cm, ovadas, ápice agudo e mucronado, nervadas; brácteas florais amarelas, 2,1-3x1,4-1,9($2,3) \mathrm{cm}$, ovadas, ápice agudo a obtuso, levemente encurvado, carenadas ou não, mais curtas que as sépalas. Flores $4,5 \mathrm{~cm}$ compr., dísticas, suberetas; sépalas amarelas, 2,5-3,2×0,8 cm, estreito-elípticas, ápice obtuso a retuso, nervadas; pétalas amarelas, 3,7-4,2x0,4-0,5 cm, liguladas, apêndices petalíneos lineares; estames exsertos, anteras dorsifixas. Frutos cerca de 3,5 cm compr. Sementes não vistas.

Material examinado: Minas Gerais, Caldas, ASEPB, 13.XI.2009, A. E. M. Rosa 171 (HRCB); 13.XI.2009, A. E. M. Rosa 172 (HRCB); 13.I.2010, A. E. M. Rosa 209 (HRCB); 13.XI.2010, A. E. M. Rosa 371 (HRCB); 13.XI.2010, A. E. M. Rosa 372 (HRCB).

Vriesea friburgensis var. tucumanensis ocorre no Paraguai, norte da Argentina e Brasil, em MG, SP, PR, SC e RS (Smith \& Downs 1977, Forzza et al. 2010), em Mata Atlântica (Forzza et al. 2010). Na ASEPB, aparece em matas ciliares da FESM, entre 1000 e 1200m de altitude. Geralmente é epífita, mas pode ser terrestre quando há abundância de matéria orgânica em decomposição. Lima (2008), considerando Caldas como pertencente a Serra da Mantiqueira, relatou que indivíduos deste táxon foram registrados somente duas vezes para esta serra, em Caldas e Pouso Alegre. A espécie floresce entre novembro e janeiro. Um espécime em frutificação foi coletado em janeiro. Em decorrência da antropização, fragmentação e pisoteio de gado nas matas ciliares localizadas nas áreas mais baixas da ASEPB, a população de Vriesea friburgensis var. tucumanensis é maior nas proximidades do Balneário Municipal, onde há cercamento da área.

18. Vriesea regnellii Mez in Mart., Eichler \& Urban, Fl. bras. 3(3): 548. 1894.

Fig. 4. K-L.

Epífita ou saxícola, 1,20-1,48 m alt. Roseta infundibuliforme. Folhas $86-92 \mathrm{~cm}$ compr., alternoespiraladas, congestas, bainha castanho-escura na face abaxial e castanho-clara na face adaxial, 17$18 \times 12-13 \mathrm{~cm}$, elíptica; lâmina verde, $68-72 \times 6,5-7,6 \mathrm{~cm}$, ligulada, com ápice agudo, mucronado. Escapo verde, $77-95 \mathrm{~cm}$ compr, glabro, ereto a levemente recurvo; brácteas escapais verdes, sem máculas, as proximais foliáceas, as distais 4,3-6x3-3,3 cm, largoovadas, ápice agudo e mucronado, imbricadas, ultrapassando os entrenós. Inflorescência 52-67×11$13 \mathrm{~cm}$, simples, racemosa, ereta, raque geniculada em direção ao ápice, entrenós $(0,8-) 1(-1,2) \mathrm{cm}$, o primeiro entrenó com cerca de $3 \mathrm{~cm}$; brácteas florais verdes, 2,7-3,9x2,2-2,7 cm, largo-ovadas a suborbiculares, ápice agudo, mais curtas que as sépalas, decorrentes, sem máculas. Flores $5,5 \mathrm{~cm}$ compr., dísticas, patentes a reflexas na antese, curto-pediceladas, pedicelo 0,5-1 $\mathrm{cm}$; sépalas verdes, 4-4,3×1,3-1,8 cm, estreitoelípticas a oblongas, ápice agudo, obtuso ou arredondado; pétalas amareladas a pardacentas na antese, 4,8-5,5×2,5 cm, obovadas a obtruladas, ápice obtuso; apêndices petalíneos $1,5 \mathrm{~cm}$, estreitotriangulares; estames inclusos, anteras dorsifixas. Frutos $5,5 \mathrm{~cm}$ compr. Sementes não vistas.

Material examinado: Minas Gerais, Caldas, ASEPB, Pedra Branca, 14.X.2009, A. E. M. Rosa 155 (HRCB); Pedra Branca, 17.XII.2009, A. E. M. Rosa 189 (HRCB); caminho para a Pedra Branca, 22.II.2010, A. E. M. Rosa 223 (HRCB).

Material adicional: Minas Gerais, Caldas, sem data, A. F. Regnell III 1799 (US 204813).

Vriesea regnellii integra o grupo Vriesea platynema Gaudich., pertencente à Seção Xiphion (E. Morren) E. Morren ex Mez, cuja dificuldade de delimitação dos táxons motivou um recente trabalho revisivo (Moura 2011). O autor registrou a ocorrência de Vriesea regnellii em Minas Gerais (Caldas) e São Paulo (Amparo). Coser et al. (2010) encontraram a espécie no Parque Estadual do Itacolomi, exclusivamente em afloramentos rochosos. Desde a descrição do tipo com base nas coletas de Regnell em Caldas, passaram-se aproximadamente 140 anos sem novos registros para a espécie. Entretanto, alguns espécimes foram vistos fora dos limites da ASEPB e é provável que trabalhos posteriores ampliem os conhecimentos sobre sua distribuição para outros municípios do Planalto Sul de Minas. Na ASEPB, Vriesea regnellii ocorre em FESM, entre 1000 e $1600 \mathrm{~m}$. Nas matas da primeira plataforma rochosa da Pedra Branca, uma área de transição entre FESM, FESA e Campos de Altitude, poucos indivíduos se estabelecem. Quando epífita, aparece nos ramos mais altos das árvores ou no terço inferior de árvores próximas à borda de mata. Também é encontrada como saxícola, nas bordas de matas úmidas. Aparece nas áreas mais preservadas, montanhosas e úmidas da ASEPB, principalmente entre a Pedra Branca, Pedra do Coração e proximidades do Balneário Municipal. Na ASEPB, Vriesea regnellii floresce em novembro e dezembro e frutifica em fevereiro.

19. Vriesea sceptrum $\mathrm{Mez}$ in C.DC., Monogr. Phan. 9: 606. 1896.

Fig. 4. M.

Epífita, rupícola, terrestre ou saxícola, 0,95$1,21 \mathrm{~m}$ alt. Roseta infundibuliforme. Folhas $50-80 \mathrm{~cm}$ compr., alterno-espiraladas, congestas, bainha castanho-escura na face abaxial e castanho-clara na adaxial, 16-21x10,5-12 cm, elíptica; lâmina verde, 3259×5,5-6 cm, ligulada, ápice agudo, mucronado. Escapo alvo-esverdeado a avermelhado em direção ao ápice, $37-55 \mathrm{~cm}$ compr., ereto, encoberto pelas 
brácteas escapais; brácteas escapais proximais foliáceas, as distais vermelho-alaranjadas, 13,5$25,5 \times 3,2-4,5 \mathrm{~cm}$, triangulares a estreito-triangulares, ápice agudo, mucronado, imbricadas, recobrindo 0 escapo. Inflorescência 45-76×17-22 cm diâm., composta, em racemo heterotético duplo, ereta, ramos eretos a suberetos, levemente geniculados, pedúnculo 5,5-7 cm, com uma bráctea estéril no ápice dos ramos e/ou na base dos ramos proximais, entrenós 0,7-1,5 $\mathrm{cm}, \quad 7-10$ flores por ramo; brácteas primárias alaranjadas, 9-16×3,5-5 cm, triangulares a ovadas, ápice agudo, mucronado, mais longas que 0 pedúnculo, as proximais cobrindo até $2 / 3$ do ramo;

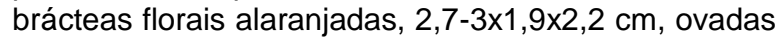
a largo-elípticas, ápice agudo a obtuso, mais curtas que as sépalas, carenadas, encurvadas em direção ao ápice, decorrentes. Flores $4,5 \mathrm{~cm}$ compr., dísticas, suberetas na antese; sépalas amareladas, 2,43,1×0,7-0,8 cm, elípticas, ápice agudo a obtuso, nervadas; pétalas alaranjadas, 3,2-4x0,3-0,5 cm, liguladas; estames inclusos, anteras dorsifixas. Frutos não vistos. Sementes não vistas.

Material examinado: Minas Gerais, Caldas, ASEPB, Pedra Branca, 23.VII.2009, A. E. M. Rosa 101 (HRCB); Pedra Branca, 3.VIII.2010, A. E. M. Rosa 285 (HRCB); Pedra Branca, 3.VIII.2010, A. E. M. Rosa 287 (HRCB); Pedra Branca, 20.X.2010, A. E. M. Rosa 355 (HRCB); Pedra Branca, 20.X.2010, A. E. M. Rosa 357 (HRCB).

Material adicional: Minas Gerais, Caldas, 1862, A. F. Regnell III 1254 (US 934181).

Vriesea sceptrum ocorre em MG, SP e RJ (Smith \& Downs 1977). Para Forzza et al. (2010), além destes estados, ocorre também no Nordeste, em Cerrado e Mata Atlântica, enquanto para Lima (2008) é típica da Serra da Mantiqueira. Na ASEPB, é nítida sua exclusividade nos Campos de Altitude, em forófitos isolados na matriz rochosa e na sua transição com a FESA, de $1500 \mathrm{~m}$ até $1760 \mathrm{~m}$ (topo da Pedra Branca). Apesar de ser bastante comum nesta fisionomia, seu potencial ornamental somado à antropização de seu habitat pode causar impactos negativos em sua população. Os espécimes analisados neste trabalho pertencem à mesma população do tipo nomenclatural, descrito com base em material de Regnell. Este fato pode justificar a presença de uma bráctea floral estéril na base dos ramos inferiores, provavelmente uma característica da população local, tendo em vista que outros espécimes consultados não a apresentavam. Floresce em julho e agosto. Em outubro alguns poucos indivíduos estão no final da floração.

\section{Agradecimentos}

Ao CNPq pela concessão da bolsa de Mestrado à primeira autora; ao professor Dr. Pedro Luis Rodrigues de Moraes, pelas referências sobre Regnell; aos professores Dr. Cláudio Coelho de Paula e Dr. Júlio Antônio Lombardi, pelas correções e sugestões; ao amigo Lucas Heldt pela ajuda nos trabalhos de campo.

\section{Referências}

COFFANI-NUNES, J.V., VERSIEUX, L.M., WANDERLEY, M.G.L. \& PIRANI, J.R. 2010. Flora da Serra do Cipó, Minas Gerais: Bromeliaceae - Tillandsioideae. Bol. Bot. Univ. São Paulo 28 (1): 35-54.

CONFORTI, T.B., RAMOS, E., ADAMI, S.F., ROSAS, P.F.C., FILHO, J.J.B., CAPONI, H.L. \& PARDALIS, A.A. 2007. Zoneamento Ambiental da APA "Santuário Ecológico da Pedra Branca", unidade de conservação municipal, Caldas, MG. Relatório técnico apresentado ao CODEMA de Caldas, MG.

COSER, T.S., PAULA, C.C. \& WENDT, T. 2010. Bromeliaceae Juss. nos campos rupestres do Parque Estadual do Itacolomi, Minas Gerais, Brasil. Rodriguésia 61(2): 261-280.

DAHLGREN, K.V.O. 1962. Anders Fredrik Regnell och hans svenska gäster i brasilien, särskilt Gustaf $A$. Lindberg och Salomon E. Henschen. Svensk Botanisk Tidskrift 56 (3): $391-470$

FARIA, A.P.G., WENDT, T. \& BROWNS, G.K. 2010. A revision of Aechmea subgenus Macrochordion (Bromeliaceae) based on phenetic analyses of morphological variation. Bot. Jour. Linn. Soc. 162: 1-27.

FORZZA, R.C., COSTA, A., SIQUEIRA FILHO, J.A. \& MARTINELLI, G. 2010. Bromeliaceae in Lista de Espécies da Flora do Brasil. Jardim Botânico do Rio de Janeiro. (http://floradobrasil.jbrj.gov.br/ 2010/FB000066).

GUARÇONI, E.A.E., PAULA, C.C. \& COSTA, A.F. 2010 Bromeliaceae do Parque Estadual da Serra do RolaMoça, Minas Gerais. Rodriguésia 61(3): 467-490.

HOLMGREN, P.K., HOLMGREN, N.H. \& BARNETT, L. 1990. Index herbariorum. Ed. 8. New York Botanical Garden. New York.

LIMA, T.T. 2008. Bromeliaceae da Serra da Mantiqueira: distribuição geográfica e conservação. Dissertação de Mestrado. Instituto de Botânica da Secretaria de Meio Ambiente. São Paulo.

LUTHER, H.E. 2008. An alphabetical list of bromeliad binomials. $11^{\text {th }}$ ed. The Bromeliad Society International. Sarasota.

MARTINELLI, G. 1989. Campos de Altitude. Editora Index. Rio de Janeiro.

MARTINELLI, G., VIEIRA, C.M., GONZALEZ, M., LEITMAN, P., PIRATININGA, A., COSTA, A.F. \& FORZZA, R.C. 2008. Bromeliaceae da Mata Atlântica brasileira: Lista de espécies, distribuição e conservação. Rodriguésia 59 (1): 209-258.

MOURA, R.L. 2011. Revisão taxonômica do grupo Vriesea platynema Gaudich. (Bromeliaceae). Tese de Doutorado. Universidade Federal do Rio de Janeiro. Rio de Janeiro. 
PAULA, C.C. 1998. Florística da família Bromeliaceae no Parque Estadual da Serra do Brigadeiro, Minas Gerais, Brasil. Tese de Doutorado. Universidade Estadual Paulista. Rio Claro.

PIMENTA, R.O. 1998. O povoamento do Planalto da Pedra Branca, Caldas e Região. São Paulo: Ed. do autor. 284p.

RADFORD, A.E., HARDIN, J.W. \& MICHEL, J.T. 1974 Phytography - Morphological evidence. In: A.E. Radford, W.C. Dickison, J.R. Massey \& C.R. Bell (eds) Vascular Plant Systematics. Harper \& Row, New York.

SCOLFORO, J.R.S., OLIVEIRA, A.D. \& CARVALHO, L.M.T. 2008. Zoneamento Ecológico-Econômico do Estado de Minas Gerais - Componentes Geofísico e Bióticos. Editora UFLA. Lavras.

SMITH, L.B. \& DOWNS, R.J. 1974. Bromeliaceae (Pitcairnioideae). Flora Neotropica Monograph 14(1): 1662.

SMITH, L.B. \& DOWNS, R.J. 1977. Bromeliaceae (Bromelioideae). Flora Neotropica Monograph 14(2): 663-1492.
SMITH, L.B. \& DOWNS, R.J. 1979. Bromeliaceae (Tillandsioideae). Flora Neotropica Monograph 14(3): 1493-2142.

TINÓS, T.M. 2011. Mapeamento geológico-geotécnico a partir de metodologia de análise integrada: ensaio de aplicação no município de Poços de Caldas - MG. Dissertação de Mestrado. Universidade Estadual Paulista. Rio Claro.

VELOSO, H.P., RANGEL FILHO, A.L.R. \& LIMA, J.C.C. 1991. Classificação da vegetação brasileira, adaptada a um sistema universal. IBGE. Departamento de Recursos Naturais e Estudos Ambientais. Rio de Janeiro.

VERSIEUX, L. \& WENDT, T. 2006. Checklist of Bromeliaceae of Minas Gerais, with notes on taxonomy and endemism. Selbyana 27(2): 107-146.

WANDERLEY, M.G.L. \& MARTINS, S.E. (orgs.). 2007. Bromeliaceae. In M.G.L. Wanderley, G.J. Shepherd, T.S. Melhem \& A.M. Giulietti (coords.). Flora fanerogâmica do Estado de São Paulo, Instituto de Botânica, São Paulo, v. 5, p.39-161.

WINTERS, A.A.M. 1981. A geologia do Maciço Sienítico da Pedra Branca, Caldas-MG. Dissertação de Mestrado. Universidade de São Paulo. São Paulo. 